\title{
BMJ Open Use of probiotics to correct dysbiosis of normal microbiota following disease or disruptive events: a systematic review
}

\author{
Lynne V McFarland
}

To cite: McFarland LV. Use of probiotics to correct dysbiosis of normal microbiota following disease or disruptive events: a systematic review. BMJ Open 2014;4:e005047.

doi:10.1136/bmjopen-2014005047

- Prepublication history for this paper is available online. To view these files please visit the journal online (http://dx.doi.org/10.1136/ bmjopen-2014-005047).

Received 29 July 2014 Accepted 30 July 2014
CrossMark

\section{Department of Medicinal Chemistry, School of Pharmacy, University of Washington, Seattle, Washington, USA}

Correspondence to Dr Lynne V McFarland; LVMCFARL@u.washington. edu

\section{ABSTRACT}

Objective: To assess the evidence for the claim probiotics can correct dysbiosis of the normal microbiota resulting from disease or disruptive events. Setting: Systematic review of published clinical trials of patients receiving a probiotic intervention for the prevention or treatment of various diseases.

Data sources: Sources searched (1985-2013): PubMed, EMBASE, Cochrane Database of Systematic Reviews, CINAHL, AMED and ISI Web of Science. Three on-line clinical trial registries were searched: Cochrane Central Register of Controlled trials, MetaRegister of Controlled Trials and National Institutes of Health.

Review methods: Included studies were randomised clinical trials of probiotic interventions having microbiological assays. Studies were evaluated following Preferred Reporting Items for Systematic Reviews and Meta-Analyses guidelines for specific probiotic strains. A standard data extraction form was used to collect the raw data.

Outcome measures: The primary outcome is the degree of microbiota correction by specific probiotic strains. Secondary outcome was the association between the degree of dysbiosis correction and clinical efficacy.

Results: The review of the literature found three distinct study designs: model A (restoration) assayed patients enrolled with a healthy, undisturbed microbiota and then assayed postdisruptive event and probiotic therapy; model B (alteration) assayed patients with pre-existing disrupted microbiota and then postprobiotic therapy; model $\mathrm{C}$ (no dysbiosis) assayed volunteers with no disruptive event prebiotic and postprobiotic. From a total of 63 trials, $83 \%$ of the probiotic products using model $A$ restored the microbiota, $56 \%$ using model $B$ improved the microbiota and only $21 \%$ using model $C$ had any effect on microbiota. Clinical efficacy was more commonly associated with strains capable of restoration of the normal microbiota.

Conclusions: The ability to assess the degree of dysbiosis improvement is dependent on the enrolled population and the timing of microbiological assays. The functional claim for correcting dysbiosis is poorly supported for most probiotic strains and requires further research.

Trial registration number: PROSPERO (CRD42014007224).

\section{Strengths and limitations of this study}

- A comprehensive review of the published literature from 1985-2013.

- Literature search unrestricted by language or country.

- Analysis of study designs resulted in novel strategy to limit bias and classify outcomes.

- Three types of outcomes of dysbiosis applied to evidence-based studies of specific probiotic strains.

- Author has over 30 years of research experience in the probiotic field.

- Pooled clinical trials using different study populations.

- Pooled probiotic doses and regimens.

- Indirect evidence linking probiotic strains and dysbiosis.

- Review performed by sole author.

\section{INTRODUCTION}

The popularity of probiotics has expanded exponentially recently, but along with their increased use, debate rages on how probiotics should be regulated and whether probiotics should be considered as a medical food, drug or a food supplement. In the USA, probiotics are typically available as dietary supplements and thus are limited to 'structure or function' health claims and, unlike prescription drugs, are not permitted to claim to 'treat' or 'cure' disease. In Europe and the UK, probiotics are allowed to have health or function claims. These claims are required to be supported by well-conducted human trials in the targeted population or in healthy volunteers, but the European Food Safety Authority (EFSA) has rejected $>80 \%$ of claims submitted to them. ${ }^{1-3}$ In many cases, scientific substantiation of a specific health claim was judged insufficient or based on an indirect effect. ${ }^{4}$ One such functional claim made for probiotic products is they correct dysbiosis (or the disruption of bacterial and fungal species after antibiotics or other disruptive exposures) and thus may be 
beneficial to maintain health. Probiotics are active during this susceptible window from the time of the disruptive event to the time when normal microbiota is restored. A wide variety of mechanisms-of-action have been documented for probiotics (ranging from blocking pathogen attachment sites, destruction of the pathogen by bacteriocins or proteases that degrade toxins, to regulation of the immune system), ${ }^{56}$ and while clinical evidence supports efficacy of some probiotic strains, the evidence linking these mechanisms-of-action to a specific health or function claims is not as clear.

A classic example of the consequence of dysbiosis is antibiotic-associated diarrhoea (AAD).$^{78}$ While antibiotics may be effective in the elimination of pathogenic organisms, a common, unintended effect is the killing or inhibition of beneficial microbes due to shared susceptibility to the antibiotic. One of the many functions for normal microbiota is the ability to resist infection by pathogenic organisms, termed 'colonisation resistance. ${ }^{10}$ The loss of a subpopulation of the normal microbiota, for example, can lead to the loss of the ability to break down fibres and starches into absorbable short chain fatty acids, resulting in high level of undigested carbohydrates, which can trigger diarrhoea. ${ }^{11}$ Disruption of the normal microbiota has been shown to lead to higher rates of infections in other body systems other than the intestinal tract including the skin, ${ }^{12}{ }^{13}$ vagina, ${ }^{14}{ }^{15}$ respiratory tract, ${ }^{16} 17$ and in the buccal cavity. ${ }^{18-20}$

The major challenge to establishing a cause and effect for the improvement of dysbiosis by probiotics is a lack of a standard definition of 'normal' microbiota. There is substantial inter-individual variation of the species of microbes present at different body niches, which also varies by age, geographic area and health status of the host. In addition, a complete accounting of the microbiota is currently impossible, as there are no assays to detect all of $>10^{13}-10^{14}$ organisms in the intestines and standard microbial culturing methods miss $75-95 \%$ of these organisms. ${ }^{21} 22$ The development of metagenomics (cataloguing individual and diseasespecific bacterial gene profiles) and the creation of the international Human Microbiome Project ushered in a new era for our understanding of the complexity of these interactions within the body. ${ }^{23} 24$ This paradigm shift from culturing to metagenomic analysis has expanded our ability to document shifts in microbial populations to an unparalleled degree, but the interpretation of these shifts continues to be under debate. ${ }^{25-28}$ With the advent of these newer metagenomic tools, the role of probiotics in the restoration of normal microbiota is being revisited. ${ }^{29}$

In light of new guidance documents and recommendations, the goal of this systematic review is to determine how claims for the restoration of the normal microbiota and the correction of dysbiosis have been studied using well-designed trials and which probiotic strains have evidence-based data to support these claims.

\section{METHODS}

\section{Study objective}

To systematically review the literature to analyse the evidence for the claim probiotics can correct dysbiosis of the normal microbiota from randomised controlled trials.

\section{Search strategy}

Search terms included: probioticsthealth claims, restoring normal microbiota, dysbiosis, normal microbiota, pharmacokinetics, metagenomics, probiotics, dietary supplements, randomised controlled trials, AAD, Clostridium difficile infection (CDI), inflammatory bowel disease (IBD), irritable bowel syndrome (IBS), traveler's diarrhoea (TD), eradication of Heliobacter pylori, bacterial vaginosis $(\mathrm{BV})$ or vaginitis, treatment of acute paediatric diarrhoea and specific probiotic strains or products. Search strategies were broad-based initially, then narrowed to clinical trials with probiotics.

\section{Data sources}

PubMed (1985-2013), EMBASE (1985-2013), Cochrane Database of Systematic Reviews (1990-2013), CINAHL (1985-2013), AMED (1985-2013) and ISI Web of Science (2000-2013). Three on-line clinical trial registries were searched: Cochrane Central Register of Controlled trials (http://www.cochrane.org), MetaRegister of Controlled Trials (http:www.controlled-trials.com/mrct) and National Institutes of Health (http://www.clinicaltrials.gov).

\section{Criteria for study selection and data extraction}

Abstracts of all citations were reviewed by a single author and rated for inclusion for randomised controlled trials of probiotic treatments. Full articles were retrieved if normal microbiota assays were mentioned. Non-English language trials were translated and included whenever possible. Exclusion criteria included preclinical studies (animal models or in vitro assays), safety or phase 2 studies, reviews, efficacy trials with no assays for normal microbiota species, metagenomic methods only, mechanism of action of normal microbiota or probiotic, crosssectional surveys, case reports or case series, duplicate reports or trials of unspecified types of probiotics. All pharmacokinetic studies in humans were reviewed, as abstracts often did not include normal microbiota assay data. Data extraction and the review process followed the Preferred Reporting Items for Systematic Reviews and Meta-Analyses (PRISMA) statement guidelines using a 27-item checklist and flow diagram. ${ }^{30} \mathrm{~A}$ standardised data extraction form was used to collect data on the probiotic (strain type, daily dose, duration), type of controls (placebo, active or no treatment), study design (status of microbiota at baseline and follow-up times), type of microbiota assay (microbial culturing, molecular biomarkers, etc), enrolled study population (adult vs paediatric, healthy volunteers, disease condition), type and timing of disruptive agent (antibiotics, chemotherapy, etc), study size and attrition, outcome assessment (efficacy 
and/or microbiota status at end of study, adverse events) and type of health claim.

\section{Outcomes and definitions}

The primary outcome is the degree of microbiota correction or improvement by specific probiotic strain(s). The secondary outcome is the association between the degree of dysbiosis correction and the net efficacy found from randomised controlled trials of probiotic interventions. Dysbiosis is defined as an alteration or disruption of the normal microbiota (bacterial or fungal species) due to exposure of an disruptive factor (such as antibiotics, chronic disease, stress, medical procedures or medications, etc). As there is no current standard definition of 'normal' microbiota, for this review, restoration of normal microbiota is defined as a return to the assayed microbial species or profile taken from a healthy individual (before a disruptive event has occurred). Included studies are required to have at least a preprobiotic treatment assay and a postprobiotic treatment assay. A variety of microbial assays were available during the search period (1985-2013), including documentation of the microbiota by either microbial cultures or metagenomic methods (16s rRNA-targeted probes using fluorescent in situ hybridisation (FISH) or other PCR technique) 8212831 or by indirect methods (Nugent scores). ${ }^{15}$ Nugent scores (ranged 0-10) are used to diagnose bacterial vaginosis (scores $\geq 7$ ) or normal vaginal microbiota (scores 0-3) based on the quantitated morphotypes of small Gram-negative rods (Gardnerella vaginalis/bacteroides spp) and curved Gram-negative rods (Mobiluncus spp) from Gram stains of vaginal discharge smears. Microbial assays of only the strain(s) contained in the probiotic product are considered as pharmacokinetic studies and were not included in the normal microbiota profiles.

\section{Models of dysbiosis}

To determine the impact on normal microbiota, only direct evidence of microbiota change (species, profiles, diversity indices or diagnostic criteria) were included and indirect effects were excluded (changes in intestinal enzymes, immune system parameters or disease symptoms). The degree to which dysbiosis was improved is categorised into three levels: (1) recovery of the normal microbiota back to baseline levels; (2) alteration or improvement of the normal microbiota; and (3) no change in normal microbiota.

The literature contained three dysbiosis models: model A (restoration of the normal microbiota), which assayed patients enrolled with a healthy, undisturbed microbiota and then assayed again after a disruptive event (such as antibiotic exposure) and probiotic therapy occurred; model B (alteration of the microbiota) assayed patients with pre-existing disrupted microbiota (eg, pre-existing chronic disease or active disease) and then post-probiotic therapy; model $\mathrm{C}$ (no dysbiosis) assayed volunteers with no disruptive event (before or during the clinical trial) at both preprobiotic and postprobiotic times, as shown in figure 1. 'Recovery' of the normal microbiota is defined as a restoration of the microbiota back to a normal healthy baseline. Recovery may be complete recovery (all assayed microbial levels returned to baseline) or incomplete recovery (partial recovery of some microbial strains, but not all returned to baseline levels). In studies enrolling participants with dysbiosis at baseline (typically due to chronic diseases), it is not possible to show a restoration to normal microbiota levels because a normal, undisturbed microbiota was not present in these types of study participants at the time of enrolment. Therefore, the strongest claim possible for model B designs is for an 'alteration or improvement' of the microbiota. Only data from the probiotic-exposed participants were analysed in this paper. Data from the control groups were used to confirm dysbiosis for participants with chronic diseases or after a disruptive exposure, such as antibiotics or chemotherapy, unaffected by probiotic exposure. ${ }^{32-34}$

\section{Assessment of methodological strength and quality}

The GRADE (Grading of Recommendations, Assessment, Development and Evaluation) system for rating overall study quality will be used for each probiotic strain or type (single strains and mixtures of strains). ${ }^{35}$ Recommendation for the support of the claim of each probiotic strain or mixture can be assessed by the overall strength of the evidence ('strong', many randomised controlled trials show significant recovery of the microbiota or 'moderate' only one randomised controlled trial; or 'weak', only case series or reports, limited number of small trials, etc).

Quality of the evidence is based on study design and graded as 'high quality' (well-defined study design for determining restoration with normal microbiota, model A), or 'moderate quality' (disrupted microbiota at baseline, model B), or 'low quality' (no disruptive event occurred, model C). Measurement of publication bias was not assessed for this review, as pooled outcome estimates of efficacy were not carried out, as typical in meta-analysis, but all studies with assays of microbiota were included to limit bias.

\section{Net efficacy rating}

To determine if the ability to correct dysbiosis is associated with clinical efficacy, the published literature for randomised controlled trials (RCTs) or meta-analyses of probiotics for various disease indications, including $\mathrm{AAD},{ }^{5}{ }^{36}{ }^{37} \mathrm{CDI},{ }^{5}{ }^{38} \mathrm{IBD},{ }^{39} \mathrm{IBS},{ }^{40} \mathrm{TD},{ }^{41}$ eradication of H. pylori, ${ }^{36}{ }^{37} \mathrm{BV}^{42}$ and treatment of acute paediatric diarrhoea was reviewed. ${ }^{43-45}$ The net rank was calculated by subtracting the number of RCTs showing nonsignificant or equivalent efficacy from the number of RCTs having significant efficacies. The ranks were categorised as follows:++, $\geq 2$ net RCTs showing significant efficacy;+, net of one RCT showing significant efficacy; 0, equal number of RCTs showing significant and nonsignificant efficacy results and,$- \geq 1$ net negative or non- 


\section{Time sequence of events}

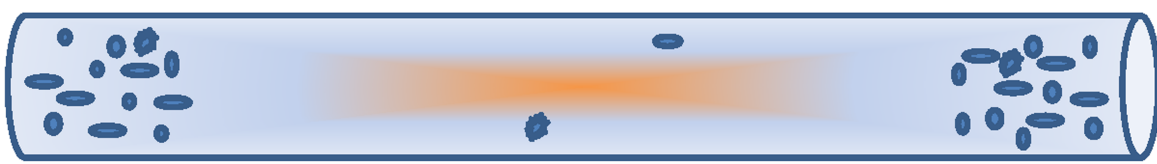

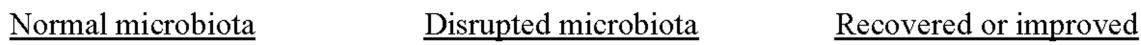

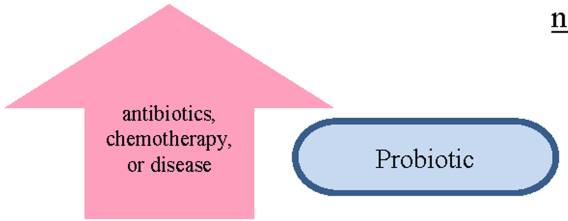

normal microbiota

\begin{tabular}{|c|l|c|c|c|c|}
\hline Model & $\begin{array}{c}\text { Type of } \\
\text { population } \\
\text { enrolled }\end{array}$ & $\begin{array}{c}\text { Dysbiosis } \\
\text { at baseline }\end{array}$ & $\begin{array}{c}\text { Time } \\
\text { microbiota } \\
\text { disrupted }\end{array}$ & $\begin{array}{c}\text { Probiotic or control } \\
\text { intervention }\end{array}$ & $\begin{array}{c}\text { Potential } \\
\text { outcomes }\end{array}$ \\
\hline A & $\begin{array}{l}\text { Healthy } \\
\text { volunteers or } \\
\text { at-risk } \\
\text { patients }\end{array}$ & no & post-baseline & preventive & restoration \\
\hline B & $\begin{array}{l}\text { Patients with } \\
\text { active disease } \\
\text { at enrollment }\end{array}$ & yes & pre-baseline & treatment & $\begin{array}{c}\text { altered or } \\
\text { improved }\end{array}$ \\
\hline C & $\begin{array}{l}\text { Healthy } \\
\text { volunteers }\end{array}$ & no & not disrupted & preventive & altered \\
\hline
\end{tabular}

Figure 1 Time sequence of events and three models of study designs determining three different degrees of dysbiosis correction by probiotics.

significant RCTs. Probiotics with no RCTs were not ranked.

\section{RESULTS}

A review of the literature from 1985-2013 found 353 articles that dealt with probiotic treatments and their potential effect on normal microbiota.

\section{Excluded studies}

As shown in figure 2, a total of 272 articles were excluded for the following reasons: reviews $(n=116)$, probiotic efficacy studies with no data on normal microbiota assays $(n=54)$, animal models of probiotics and changes in microbiota $(n=38)$, metagenomic or microbiota methods only $(n=17)$, studies on normal microbiota but with no use of probiotics $(n=14)$, in vitro assays of microbiota $(n=10)$, duplicative reports $(n=2)$ or miscellaneous $(n=21)$, which included probiotic mechanism of action studies, safety studies, duplicative reports, cross-sectional surveys and two with poorly described probiotic interventions. ${ }^{46} 47$ A total of 81 full articles were reviewed which mentioned changes in normal microbiota or indicated a health claim for probiotics and effects on normal microbiota.

Probiotic pharmacokinetic studies $(n=18)$ reporting concentrations of probiotic strains before and post- treatment, but not assaying for other species of normal microbiota were excluded. While several studies using this study design claim probiotics had an impact on normal microbiota, type of data generated is pharmacokinetic behaviour of the probiotics themselves and not the normal microbiota. Several studies stated that the normal microbiota was altered because an increase in various bacterial species was observed after the probiotics were given, but the species assayed were those contained in the probiotic product, so an increase is not unexpected. Pharmacokinetic studies have documented that probiotic strains taken orally can survive transit through the intestinal tract with recovery rates in faeces ranging from $<1 \%$ to $22 \%{ }^{48}{ }^{49}$ These pharmacokinetic studies were excluded from this analysis, as they did not assay other types of normal microbiota not found in the probiotic product.

\section{Included studies}

Of the 63 included clinical trials, five trials had multiple treatment arms, which resulted in a total of 69 treatment arms for analysis. Engelbrektson et $a \bar{\nu}^{0}$ tested a mixture of five probiotic strains in volunteers exposed to antibiotics and also tested a mixture of four probiotic strains in healthy volunteers with no antibiotic exposure. Zoppi et $a \bar{l}^{1}$ had eight different treatment arms in his study, 


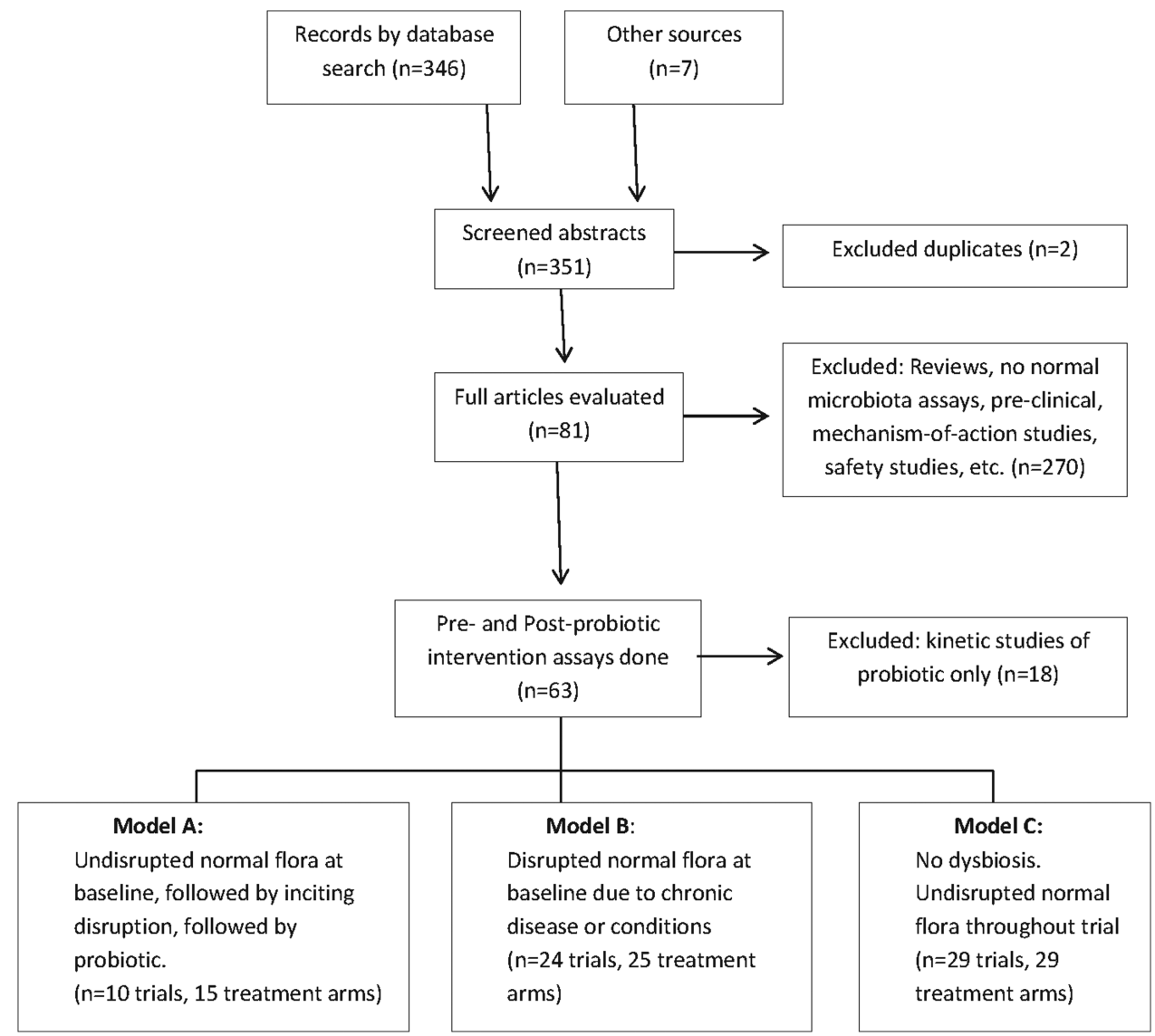

Figure 2 Flow chart of literature review results (1985-2013) of included and excluded studies for the restoration or improvement of normal microbiota by probiotics. RCT, randomised-controlled trials; MOA, mechanism of action; NM, normal microbiota.

and probiotic arms were included in our analysis (Saccharomyces boulardii alone and Lactobacillus rhamnosus $G G$ alone), a mixture of two probiotics (L. acidophilus and Bifido bifidum) and a mixture of three probiotic strains (L. acidophilus, L. rhamnosus and B. bifidum). Orrhage et $a \tilde{l}^{2}$ had two treatment arms (Bifido longum alone and a mixture of B. longum and L. acidophilus). Larsen et $a \bar{l}^{53}$ tested two single probiotics (B. lactis and L. acidophilus) in separate treatment arms. Lidbeck et $a l^{54}$ gave either enoxacin or clindamycin and randomised patients to either L. acidophilus or placebo.

\section{Normal microbiota assay methods}

Of the 69 treatment arms that did normal microbiota assays, diverse methods were used to profile the microbiota. Many studies used only standard microbiological culture assays $(37,54 \%)$, while others $(28,40 \%)$ used techniques to detect non-cultivatable bacterial strains, which included metagenomic assays (FISH, TRFLP, $16 \mathrm{~s}$ rRNA sequencing) or other PCR techniques. Some studies $(4,6 \%)$ used an indirect measure of normal microbiota, using the Nugent score to diagnose bacterial vaginosis, which relies on Gram stain of the vaginal secretions, vaginal $\mathrm{pH}$ and symptoms to characterise if normal microbiota is present or absent. ${ }^{15}$

\section{Probiotic strains}

In the 69 treatment arms, most $(36,52 \%)$ used a single strain of probiotic, while $14(20 \%)$ tested a mix of two probiotic strains and $19(28 \%)$ tested a mix of three or more probiotic strains. The distribution of single versus multiple strain probiotics did not significant vary by the model of study design $\left(\chi_{2}^{2}=2.3, \mathrm{p}=0.32\right)$. Of the 15 restorative (model A) study arms, $47 \%$ used a single strain of probiotic and $53 \%$ used multiple strains. Of the 25 treatment arms with disrupted microbiota at baseline (model B), 44\% used a single strain and 56\% used multiple strains. Of the 29 study arms with undisrupted microbiota (model C), 62\% used a single strain and $38 \%$ used multiple strains.

\section{Normal microbiota restoration model (model A)}

Only 10 studies (with 15 treatment arms) using model A to determine restoration of the microbiota were found (table 1). ${ }^{32} 34 \quad 50-52 \quad 54-58$ The type of enrolled participants varied from healthy volunteers to children with untreated respiratory infections, to paediatric cancer patients. For participants with acute infections or cancer, baseline assays were performed prior to the disrupting agent (antibiotics or chemotherapy). The number of participants given probiotics averaged 20/study and 
ranged from 5 to 83 . In 93\%, the disruptive factor was antibiotic exposure and in one study, chemotherapy caused the microbiota disruption. Only 8 (53\%) of the study arms did an assay during a 1-8 weeks follow-up period after the probiotic was discontinued.

Analysis of the probiotic strain(s) separately found only two probiotic products with more than one randomised controlled trial. The probiotic mix of $L$. acidophilus and B. bifidum showed a complete restoration in one study, but only a partial recovery in the other (Strength: strong, Quality: high). The probiotic mix of L. acidophilus (2 strains) with B. bifidum and B. animalis showed complete restoration in one study, but only a partial recovery in the other (Strength: strong, Quality: high). Five other probiotic products with only one supporting clinical trial showed microbiota restoration (B. longum, Clost. butyricum, L. acidophilus, mix of L. acidophilus with L. paracasei and B. lactis and the mix of L. acidophilus with $L$. paracasei and B. bifidum and two strains of B. lactis; Strength: moderate, Quality: high). Three probiotic products with one supporting clinical trial showed partial restoration (S. boulardii, L. rhamnosus GG, mix of L. rhamnosus with L. bifidus and L. acidophilus; Strength: moderate, Quality: high). Only two probiotic products using Model A showed no change in the microbiota (B. breve and a mix of $L$. acidophilus and B. longum; Strength: moderate, Quality: high). In summary, 10 of $12(83 \%)$ of the probiotic products showed complete or partial restoration of the normal microbiota.

Of the 11 probiotic products with claims of 'restores or improves normal microbiota', 10 (91\%) were supported by this review, but only seven showed complete restoration and five had partial restoration of the microbiota (table 1). The mixture of $L$. acidophilus and $B$. longum did not show any changes in the microbiota. Wada $e t a \ell^{2}$ claimed $B$. breve 'enhanced intestinal anaerobes', but this was only compared to the placebo group. Their data showed chemotherapy is a disruptive event, resulting in more enterobacteria in the intestine in the placebo group, but there were no significant differences seen by the end of the 8 weeks follow-up in either the probiotic or the placebo group compared to baseline microbiota levels.

\section{Disrupted normal microbiota at baseline studies (model B)}

Twenty-four studies (with 25 treatment arms) used model B that enrolled participants with a pre-existing disrupted microbiota related to ongoing disease or conditions (table 2). ${ }^{33} 53$ 59-80 The number of participants given probiotics averaged 23 \pm 16 /study and ranged from 7 to 83 participants. The types of pre-existing factors that disrupted the microbiota included atopic dermatitis patients, allergies, cirrhosis, bacterial vaginosis, irritable bowel syndrome, inflammatory bowel disease (ulcerative colitis and pouchitis), idiopathic diarrhoea, enteral feeding, short-bowel syndrome and colon cancer. Only $10(40 \%)$ of the study arms did an assay during the postprobiotic follow-up period.
Three of the probiotics had multiple clinical trials to support the claim of an improvement in the microbiota due to the probiotic. S. boulardii was used in two trials either with enteral fed patients or patients with active diarrhoea and found an improvement in the habitual microbiota in the patients with active diarrhoea, ${ }^{66}$ but only showed indirect evidence of short-chain fatty acid changes in the other study ${ }^{65}$ (Strength: strong, Quality: moderate). A mix of four probiotic strains (2 strains of $L$. rhamnosus, $P$. freudenreichii $B$. breve) showed improved microbiota in two clinical trials ${ }^{74}{ }^{75}$ (Strength: strong, Quality: moderate). Of four clinical trials testing a mixture of seven probiotic strains, two showed no significant change in microbiota, ${ }^{77}$ one showed more anaerobes postprobiotic treatment ${ }^{79}$ and one found a reduction in bacteroides species ${ }^{80}$ (Strength: strong, Quality: moderate). Three clinical trials determined there were no significant changes due to Lactobacillus plantarum 299v $\mathrm{v}^{62-64}$ (Strength: strong, Quality: moderate). Of those probiotics with only one supporting clinical trial (Strength: moderate, Quality: moderate), two single probiotic strains (E. coli Nissle and L. casei rhamnosus) and five different mixtures of probiotic strains support the claim that the probiotic alters the microbiota (table 2). In summary, 10 of $18(56 \%)$ probiotic products altered or improved microbiota in individuals with pre-existing disease.

Of the 25 treatment arms, the paper's claim was confirmed in $14(56 \%)$ of the studies. There was no significant change in the microbiota due to the probiotic in nine treatment arms and only an alteration of the microbiota in five others (table 2). Our review disagreed with the claimed outcomes in $11(46 \%)$ of the other treatment arms. In seven treatment arms, it was claimed the tested probiotic 'restored normal microbiota', but it is uncertain how this conclusion was reached, since there was no time when a normal undisrupted microbiota was present. Of the seven studies that claimed their probiotic 'restored' normal microbiota, our analysis determined none were capable of documenting restoration, but it is confirmed probiotics improved or altered the microbiota in these studies. Four studies claimed the probiotic 'altered or improved' normal microbiota, but this review found no significant differences when postprobiotic and baseline assays were compared for the probiotic groups. Girard-Pipau et al ${ }^{65}$ concluded that $S$. boulardii 'altered normal flora' because more Gram-positive anaerobes were seen in the probiotic group compared to the controls and an increase in three short-chain fatty acids were observed in the $S$. boulardii group. However, when the analysis is restricted to trends observed in the probiotic group only, no significant differences were observed in preprobiotic versus postprobiotic microbiota profiles. Venturi $e t a l^{77}$ concluded that the mix of seven probiotic strains enhanced the concentration of some beneficial strains in the intestines. However, the only strains having a significant increase were those contained in the probiotic mix, and not specifically normal 
Table 1 Evidence-based data for restoration of normal microbiota (NM) for 12 probiotics from 10 studies (15 treatment arms; model A)

\begin{tabular}{|c|c|c|c|c|c|c|c|c|}
\hline Probiotic* $^{*}$ & Reference & $\begin{array}{l}\text { Number } \\
\text { treated with } \\
\text { probiotic }\end{array}$ & $\begin{array}{l}\text { Type of } \\
\text { assay } \\
\text { for NM }\end{array}$ & $\begin{array}{l}\text { Enrolled } \\
\text { population }\end{array}$ & $\begin{array}{l}\text { Type of } \\
\text { disrupting } \\
\text { factor }\end{array}$ & $\begin{array}{l}\text { Follow-up } \\
\text { post-treatment } \\
\text { (weeks) }\end{array}$ & $\begin{array}{l}\text { Claims } \\
\text { stated in } \\
\text { papers }\end{array}$ & $\begin{array}{l}\text { Evidence-based } \\
\text { claim }\end{array}$ \\
\hline Bifido breve & Wada et $a^{\beta 2}$ & 19 & $\mathrm{FISH}$ & $\begin{array}{l}\text { Paediatric } \\
\text { cancer patients }\end{array}$ & Chemotherapy & 8 & $\begin{array}{l}\text { Enhances } \\
\text { anaerobes }\end{array}$ & No change \\
\hline Bifido longum BB536 & Orrhage et $a^{p^{2}}$ & 10 & Culture & $\begin{array}{l}\text { Healthy } \\
\text { volunteers }\end{array}$ & Clindamycin & 0 & Restores & Restores \\
\hline $\begin{array}{l}\text { Clostridium butyricum } \\
\text { MIYAIRI }\end{array}$ & Seki et $a /^{34}$ & 83 & Culture & $\begin{array}{l}\text { Paediatric } \\
\text { respiratory or } \mathrm{Gl} \\
\text { infections }\end{array}$ & Antibiotics & 0 & Restores & Restores \\
\hline \multirow[t]{2}{*}{$\begin{array}{l}\text { Lactobacillus acidophilus } \\
\text { NCFB1748 }\end{array}$} & Lidbeck et $a \Gamma^{4}$ & 5 & Culture & $\begin{array}{l}\text { Healthy } \\
\text { volunteers }\end{array}$ & Enoxacin or & 1 & $\begin{array}{l}\text { Restores } \\
\text { only in } \\
\text { enoxacin }\end{array}$ & $\begin{array}{l}\text { Restores only in } \\
\text { enoxacin }\end{array}$ \\
\hline & & 5 & Culture & Volunteers & Clindamycin & 1 & No change & $\begin{array}{l}\text { No change in } \\
\text { clindamycin }\end{array}$ \\
\hline $\begin{array}{l}\text { Lactobacillus rhamnosus } \\
\text { GG }\end{array}$ & Zoppi et $a^{\Gamma^{1}}$ & 7 & Culture & $\begin{array}{l}\text { Paediatric } \\
\text { respiratory } \\
\text { infections }\end{array}$ & Ceftriaxone & 0 & $\begin{array}{l}\text { Partially } \\
\text { corrects }\end{array}$ & Partially restores \\
\hline $\begin{array}{l}\text { Saccharomyces boulardii } \\
\text { lyo }\end{array}$ & Zoppi et $a{ }^{51}$ & 6 & Culture & $\begin{array}{l}\text { Paediatric } \\
\text { respiratory } \\
\text { infections }\end{array}$ & Ceftriaxone & 0 & Improves & Partially restores \\
\hline \multirow[t]{2}{*}{$\begin{array}{l}\text { L. acidophilus+Bifido } \\
\text { bifidum }\end{array}$} & Black et $a^{{ }^{5}}$ & 10 & Culture & $\begin{array}{l}\text { Healthy } \\
\text { volunteers }\end{array}$ & Ampicillin & 2 & $\begin{array}{l}\text { Recovers } \\
\text { more rapidly }\end{array}$ & Restores \\
\hline & Zoppi et $a^{{ }^{1}}$ & 7 & Culture & $\begin{array}{l}\text { Pediatric } \\
\text { respiratory }\end{array}$ & Ceftriaxone & 0 & Less change & Partially restores \\
\hline $\begin{array}{l}\text { L. acidophilus } 1748+B \text {. } \\
\text { longum BB536 }\end{array}$ & Orrhage et $a^{{ }^{2}}$ & 10 & Culture & $\begin{array}{l}\text { Healthy } \\
\text { volunteers }\end{array}$ & Clindamycin & 0 & No change & No change \\
\hline $\begin{array}{l}\text { L. rhamnosus+L. bifidus+L. } \\
\text { acidophilus }\end{array}$ & Zoppi et $a^{\digamma^{1}}$ & 7 & Culture & $\begin{array}{l}\text { Paediatric } \\
\text { respiratory } \\
\text { infections }\end{array}$ & Ceftriaxone & 0 & $\begin{array}{l}\text { Partially } \\
\text { corrects }\end{array}$ & Partially restores \\
\hline $\begin{array}{l}\text { L. acidophilus } 1748 \\
+ \text { Lactobacillus paracasei } \\
\text { F19+Bifido lactis Bb12 }\end{array}$ & Jernberg et $a^{56}$ & 4 & $\begin{array}{l}\text { Culture } \\
\text { PCR } \\
\text { TRFLP }\end{array}$ & $\begin{array}{l}\text { Healthy } \\
\text { volunteers }\end{array}$ & Clindamycin & 2 & Restores & Restores \\
\hline $\begin{array}{l}\text { L. acidophilus CUL60+L. } \\
\text { acidophilus CUL21+B. }\end{array}$ & Madden et $a^{p^{7}}$ & 15 & Culture & $\begin{array}{l}\text { Helicobacter } \\
\text { pylori+ }\end{array}$ & $\begin{array}{l}\text { Amoxicillin } \\
+ \text { metronidazole }\end{array}$ & 2 & Restores & Restores \\
\hline $\begin{array}{l}\text { bifidum CUL17+Bifido } \\
\text { animalis lactis }\end{array}$ & Plummer et $a^{58}$ & 76 & Culture & H. pylori+ & $\begin{array}{l}\text { Amoxicillin } \\
\text { +clarithromycin }\end{array}$ & 2 & $\begin{array}{l}\text { Restores } \\
\text { more rapidly }\end{array}$ & Partially restores \\
\hline $\begin{array}{l}\text { L. acidophilus } N C F M+L \text {. } \\
\text { paracasei } L p c-37+B \text {. } \\
\text { bifidum } \mathrm{Bb02+B} \text {. lactis } \\
\text { Bi- } 04+B \text {. lactis } \mathrm{Bi}-07\end{array}$ & $\begin{array}{l}\text { Engel-brektson } \\
\text { et af }\end{array}$ & 20 & $\begin{array}{l}\text { Culture } \\
\text { PCR } \\
\text { TRFLP }\end{array}$ & $\begin{array}{l}\text { Healthy } \\
\text { volunteers }\end{array}$ & Augmentin & 2 & Restores & Restores \\
\hline
\end{tabular}

$\mathrm{Gl}$, gastrointestinal. 
Table 2 Evidence-based data for improvement or alteration of normal microbiota (NM) in 18 probiotics from 24 studies (25 treatment arms) with disturbed microbiota at baseline (model B)

\begin{tabular}{|c|c|c|c|c|c|c|c|c|}
\hline Probiotic* $^{*}$ & Reference & $\begin{array}{l}\text { Number } \\
\text { treated with } \\
\text { probiotic }\end{array}$ & $\begin{array}{l}\text { Type(s) of } \\
\text { assay for } \\
\text { NM }\end{array}$ & $\begin{array}{l}\text { Pre-existing } \\
\text { disrupting } \\
\text { factort }\end{array}$ & $\begin{array}{l}\text { Follow-up } \\
\text { time }\end{array}$ & $\begin{array}{l}\text { Claims } \\
\text { stated in } \\
\text { papers }\end{array}$ & $\begin{array}{l}\text { Evidence-based } \\
\text { claim }\end{array}$ & $\begin{array}{l}\text { Type of change } \\
\text { found in NM }\end{array}$ \\
\hline Bifido breve M-16V & $\begin{array}{l}\text { Van der Aa } \\
\text { et } a^{59}\end{array}$ & 46 & $\mathrm{FISH}$ & $\begin{array}{l}\text { Atopic } \\
\text { dermatitis }\end{array}$ & 0 & $\begin{array}{l}\text { Modulates } \\
\text { NF }\end{array}$ & No change & - \\
\hline Bifido lactis $\mathrm{Bi}-07$ & Larsen et $a^{{ }^{3}}$ & 17 & PCR & $\begin{array}{l}\text { Atopic } \\
\text { dermatitis }\end{array}$ & 0 & No change & No change & - \\
\hline Bifido longum BB536 & $\begin{array}{l}\text { Odamaki } \\
\text { et } a \beta^{\beta 3}\end{array}$ & 22 & $\begin{array}{l}\text { TRFLP } \\
\text { PCR }\end{array}$ & $\begin{array}{l}\text { Cedar pollen } \\
\text { allergy }\end{array}$ & 4 weeks & $\begin{array}{l}\text { Maintains } \\
\text { NF }\end{array}$ & No change & - \\
\hline Escherichia coli Nissle & Lata et $a^{60}$ & 22 & Culture & Liver cirrhosis & 0 & Restores & Improves & $\begin{array}{l}\text { More Bifido and } \\
\text { Lactobacillus }\end{array}$ \\
\hline Lactobacillus acidophilus 700396 & Larsen et $a^{\rho^{3}}$ & 17 & PCR & $\begin{array}{l}\text { Atopic } \\
\text { dermatitis }\end{array}$ & 0 & No change & No change & - \\
\hline $\begin{array}{l}\text { Lactobacillus casei rhamnosus } \\
\text { Lcr35 }\end{array}$ & $\begin{array}{l}\text { Petricevic and } \\
\text { Witt }^{61}\end{array}$ & 83 & $\begin{array}{l}\text { Nugent } \\
\text { scores }\end{array}$ & $\begin{array}{l}\text { Bacterial } \\
\text { vaginosis }\end{array}$ & 4 weeks & Restores & Improves & $\begin{array}{l}\text { Improved Nugent } \\
\text { scores }\end{array}$ \\
\hline \multirow[t]{3}{*}{ Lactobacillus plantarum 299v } & Nobaek et $a^{{ }^{62}}$ & 25 & Culture & IBS & 4 weeks & No change & No change & - \\
\hline & Klarin et $a^{{ }^{3}}$ & 17 & Culture & Enterally-fed & 0 & No change & No change & \\
\hline & Klarin et $a^{64}$ & 22 & Culture & Antibiotics & 0 & No change & No change & \\
\hline \multirow[t]{2}{*}{ Saccharomyces boulardii lyo } & Girard et al ${ }^{65}$ & 10 & Culture & Enterally-fed & 9 days & Alters NF & No change & - \\
\hline & $\begin{array}{l}\text { Swidsinski } \\
\text { et } a^{\rho^{6}}\end{array}$ & 20 & FISH & Active diarrhoea & 3 weeks & Improves & Improves & $\begin{array}{l}\text { More 'habitual } \\
\text { microbiota' }\end{array}$ \\
\hline $\begin{array}{l}\text { L. rhamnosus GR-1+Lactobacillus } \\
\text { fermentum } \mathrm{RC} 14\end{array}$ & Reid et $a{ }^{67}$ & 33 & $\begin{array}{l}\text { Nugent } \\
\text { scores }\end{array}$ & $\begin{array}{l}\text { Bacterial } \\
\text { vaginosis }\end{array}$ & 2 weeks & Restores & Improves & $\begin{array}{l}\text { Improved Nugent } \\
\text { scores }\end{array}$ \\
\hline $\begin{array}{l}\text { L. rhamnosus GR-1+L. fermentum } \\
\text { RC14 }\end{array}$ & Reid et $a{ }^{68}$ & 31 & $\begin{array}{l}\text { Nugent } \\
\text { scores } \\
\text { and } \\
\text { culture }\end{array}$ & $\begin{array}{l}\text { Bacterial } \\
\text { vaginosis }\end{array}$ & 30 days & Restores & Improves & $\begin{array}{l}\text { Improved Nugent } \\
\text { scores }\end{array}$ \\
\hline $\begin{array}{l}\text { Lactobacillus plantarum 8PA3 } \\
\text { +Bifido bifidum }\end{array}$ & Kirpich et $a^{69}$ & 32 & Culture & Colon cancer & 0 & Restores & Improves & $\begin{array}{l}\text { More E. coli and } \\
\text { enterococci }\end{array}$ \\
\hline $\begin{array}{l}\text { L. rhamnosus GR1+Lactobacillus } \\
\text { reuteri RC14 }\end{array}$ & $\begin{array}{l}\text { Hummelen } \\
\text { et } a l^{70}\end{array}$ & 23 & $\begin{array}{l}\text { Nugent } \\
\text { score }\end{array}$ & $\begin{array}{l}\text { Bacterial } \\
\text { vaginosis }\end{array}$ & 0 & No change & No change & - \\
\hline L. casei Shirota $+B$. breve BBG01 & Uchida et $a l^{71}$ & 4 & Culture & $\begin{array}{l}\text { Short bowel } \\
\text { syndrome }\end{array}$ & 0 & No change & No change & - \\
\hline $\begin{array}{l}\text { L. brevis CD2+Lactobacillus } \\
\text { salivaris FV2+L. plantarum FV9 }\end{array}$ & $\begin{array}{l}\text { Mastromarino } \\
\text { et } a l^{2}\end{array}$ & 19 & $\begin{array}{l}\text { Nugent } \\
\text { score }\end{array}$ & $\begin{array}{l}\text { Bacterial } \\
\text { vaginosis }\end{array}$ & 2 weeks & Restores & Improves & $\begin{array}{l}\text { Improved Nugent } \\
\text { scores }\end{array}$ \\
\hline $\begin{array}{l}\text { L. paracasei Lpc } 37+L \text {. acidophilus } \\
74-2+\text { Bifido animalis DGCC } 420\end{array}$ & $\begin{array}{l}\text { Roessler } \\
\text { et } a l^{73}\end{array}$ & 30 & PCR & $\begin{array}{l}\text { Atopic } \\
\text { dermatitis }\end{array}$ & 0 & No change & No change & - \\
\hline $\begin{array}{l}\text { L. rhamnosus } \mathrm{GG}+\mathrm{L} \text {. rhamnosus } \\
\text { Lc705+Propionibacterium }\end{array}$ & $\begin{array}{l}\text { Kajander } \\
\text { et } a l^{74}\end{array}$ & 41 & PCR & IBS & 0 & Restores & Improves & $\begin{array}{l}\text { Improved } \\
\text { similarity index }\end{array}$ \\
\hline $\begin{array}{l}\text { freudenreichii shermanii } \mathrm{JS}+B \text {. } \\
\text { breve } \mathrm{Bb} 99\end{array}$ & Lyra et $a l^{75}$ & 22 & PCR & IBS & 0 & Alters & Alters & $\begin{array}{l}\text { More clostridia } \\
\text { and } \\
\text { Ruminococcus }\end{array}$ \\
\hline
\end{tabular}




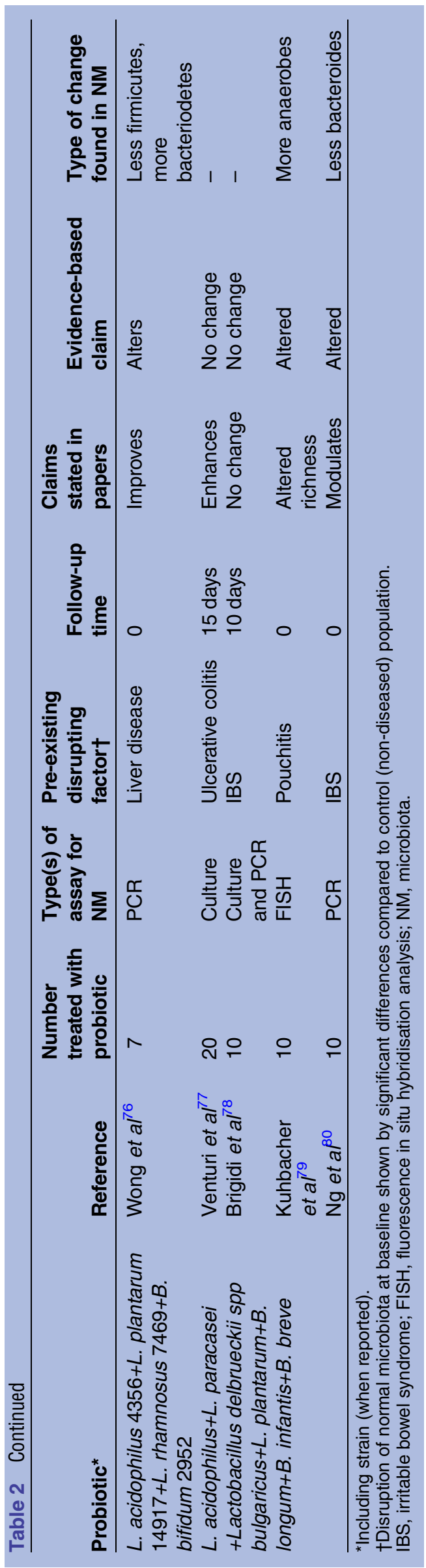

microbiota of the host. As this study did not have an undisturbed microbiota baseline, the increased numbers of lactobacilli and bifidobacteria may not have reflected their normal levels. Van der Aa et a ${ }^{59}$ claimed that $B$. breve 'successfully modulates the intestinal flora', but no significant changes were observed in the probiotic group when comparing the baseline to the postprobiotic levels. Odamaki et $a l^{33}$ did show an increase in Faecalibacterium spp and Bacteroides fragilis spp at the end of B. longum BB536 treatment, but the same increase was also observed in the placebo group.

\section{Undisrupted normal microbiota studies (model C)}

Twenty-nine trials enrolled healthy adults who had no disruptive factor present during the study (either no antibiotic or no medication exposure or presence of acute or chronic disease) that might impact normal microbiota, as shown in table $3 .^{14} 49 \quad 50$ 81-106 The average number of participants given probiotics was 23/ study and ranged from 7 to $160 /$ study. Of the 29 study arms, assays were taken during a follow-up period in only $52 \%$. Fujiwara $e t a l^{84}$ cultured seven healthy volunteers and found enterobacteriaceae and Clostridial species post- $B$. longum was reduced by $10^{1} / \mathrm{g}$ compared to baseline $(\mathrm{p}<0.03)$, but no other changes in the microbiota were detected. Karlsson $e t a t^{44}$ found a significant increase in intestinal diversity in nine male volunteers with atherosclerosis given $L$. plantarum 299v, but because terminal restriction fragment length polymorphism assays were used instead of cultures for bacterial species, the specific changes in the microbiota species could not be determined. Yang and Sheu cultured 63 children (55\% with Helicobacter pylori) given a yogurt with $L$. acidophilus and B. lactis but only found a decrease in E. coli counts in the H.pylori negative children subgroup, no significant changes in normal microbiota was found in the H. pylori-positive children. ${ }^{100}$ Kubota et $a l^{103}$ assayed 29 participants with Japanese cedar pollen allergy and found milk fermented with L. rhamnosus GG and L. gasseri TMC0356 suppressed microbiota changes (less intestinal profile changes), but could not determine specific bacterial species changes due to the type of assay used (FISH and TRFLP). ${ }^{103}$ In summary, only 4 of $19(21 \%)$ probiotic products altered microbiota in healthy individuals who had no disruptive event.

Of the seven studies that claimed their probiotic(s) 'restored or altered' the normal microbiota, only four claims were confirmed. Sierra et a $\ell^{96}$ claimed Lactobacillus salivarius given to 20 healthy adults 'improved gut microbiota', but only increased levels of Lactobacilli were found and no other changes in normal microbiota species were detected. The only other evidence was indirect from changes observed in immune parameters. He et a ${ }^{99}$ claimed a mixture of B. longum and B. animalis 'modified' microbiota, but changes were seen only during the yogurt administration and not after the 1 week follow-up period. Vitali $e a^{14}$ claimed that the mixture of four lactobacilli strains and three bifidobacteria strains 'modulated vaginal 
Table 3 Model C: Evidence-based data for improvement or alteration of normal microbiota (NM) in 19 probiotics in healthy volunteers enrolled in 29 studies (29 treatment arms) in studies with no disruptive exposures

\begin{tabular}{|c|c|c|c|c|c|c|c|c|}
\hline Probiotic* $^{*}$ & Reference & $\begin{array}{l}\text { Number } \\
\text { treated with } \\
\text { probiotic }\end{array}$ & $\begin{array}{l}\text { Type of } \\
\text { assay for } \\
\text { NM }\end{array}$ & $\begin{array}{l}\text { Enrolled } \\
\text { population }\end{array}$ & $\begin{array}{l}\text { Type of } \\
\text { disrupting } \\
\text { factor }\end{array}$ & $\begin{array}{l}\text { Follow-up } \\
\text { post-treat-ment }\end{array}$ & $\begin{array}{l}\text { Claims stated } \\
\text { in papers }\end{array}$ & $\begin{array}{l}\text { Evidence- } \\
\text { based claim }\end{array}$ \\
\hline \multirow[t]{2}{*}{ Bifido animalis lactis DN173010 } & Rochet et $a l^{49}$ & 12 & $\mathrm{FISH}$ & Healthy & None & 10 days & No change & No change \\
\hline & Oswari et $a \beta^{\beta 1}$ & 160 & PCR & Volunteers & None & 6 months & No change & No change \\
\hline Bifido bifidum & $\begin{array}{l}\text { Langhendries } \\
\text { et } a^{\beta 2}\end{array}$ & 20 & Culture & Healthy volunteers & None & 0 & No change & No change \\
\hline \multirow[t]{3}{*}{ Bifido longum } & $\begin{array}{l}\text { Benno and } \\
\text { Mitsuoka }^{83}\end{array}$ & 5 & Culture & Healthy volunteers & None & 0 & No change & No change \\
\hline & Fujiwara et a ${ }^{84}$ & 7 & Culture & & None & 30 days & Alters & Alters \\
\hline & Harmsen et $a^{85}$ & 14 & FISH & & None & 0 & No change & No change \\
\hline \multirow[t]{3}{*}{ Lactobacillus casei ND114001 } & Guerin et $a^{\beta 6}$ & 12 & Culture & Healthy volunteers & None & 1 weeks & No change & No change \\
\hline & Rochet et $a l^{\beta 7}$ & 12 & FISH & & None & 10 days & No change & No change \\
\hline & Rochet et a/88 & 7 & $\mathrm{FISH}$ & & None & 0 & No change & No change \\
\hline Lactobacillus johnsonii La1 & Brunser et $a{ }^{\beta 9}$ & 32 & $\begin{array}{l}\text { Culture } \\
\text { and FISH }\end{array}$ & Healthy volunteers & None & 2 weeks & No claim & No change \\
\hline \multirow[t]{5}{*}{ Lactobacillus plantarum 299v } & $\begin{array}{l}\text { Goossens } \\
\text { et } a^{\rho^{0}}\end{array}$ & 11 & Culture & Healthy & None & 3 weeks & No change & No change \\
\hline & $\begin{array}{l}\text { Goossens } \\
\text { et } a^{\rho^{1}}\end{array}$ & 32 & Culture & Healthy & None & 4 weeks & No change & No change \\
\hline & $\begin{array}{l}\text { Goossens } \\
\text { et } a^{\rho^{2}}\end{array}$ & 15 & Culture & Colonic & None & 0 & No change & No change \\
\hline & Berggren et $a^{\rho^{3}}$ & 33 & Culture & Polyps & None & 0 & No change & No change \\
\hline & Karlsson et $a^{\rho^{4}}$ & 9 & TRFLP & $\begin{array}{l}\text { Healthy, } \\
\text { atherosclerosis }\end{array}$ & None & 0 & Alters & Alters \\
\hline Lactobacillus rhamnosus GG & $\begin{array}{l}\text { Gueimonde } \\
\text { et } a{ }^{95}\end{array}$ & 29 & PCR & Healthy volunteers & None & 0 & No change & No change \\
\hline $\begin{array}{l}\text { Lactobacillus salivarius } \\
\text { CECT5713 }\end{array}$ & Sierra et $a^{\beta 6}$ & 20 & Culture & Healthy volunteers & None & 0 & Improves & No change \\
\hline Saccharomyces boulardii lyo & $\begin{array}{l}\text { Vanhoutte } \\
\text { et } a \beta^{7}\end{array}$ & 30 & PCR & Healthy volunteers & None & 0 & No change & No change \\
\hline \multirow[t]{2}{*}{ B. animalis $+B$. longum } & Zhong et $a^{\rho 8}$ & 11 & $\mathrm{FISH}$ & Healthy volunteers & None & 7 days & No change & No change \\
\hline & He et $a^{\rho 9}$ & 11 & $\mathrm{FISH}$ & & & 7 days & Modifies & No change \\
\hline L. acidophilus $+B$. lactis & $\begin{array}{l}\text { Yang and } \\
\text { Sheu }\end{array}$ & 63 & Culture & $\begin{array}{l}\text { Healthy but } 55 \% \\
\text { H. pylorit }\end{array}$ & None & 0 & Restores & Alters \\
\hline $\begin{array}{l}\text { L. rhamnosus } \mathrm{GG}+B \text {. longum } \\
\text { Bb536 }\end{array}$ & Mah et al ${ }^{101}$ & 20 & $\mathrm{FISH}$ & Healthy neonates & None & 6 months & No change & No change \\
\hline $\begin{array}{l}\text { L. rhamnosus } \mathrm{GG}+B \text {. lactis } \\
\mathrm{Bb} 12\end{array}$ & Rafter et al ${ }^{102}$ & 38 & Culture & $\begin{array}{l}\text { Patients with } \\
\text { colon cancer or at } \\
\text { risk }\end{array}$ & None & 0 & No change & No change \\
\hline
\end{tabular}




\begin{tabular}{|c|c|c|c|c|c|c|c|c|}
\hline Probiotic* $^{*}$ & Reference & $\begin{array}{l}\text { Number } \\
\text { treated with } \\
\text { probiotic }\end{array}$ & $\begin{array}{l}\text { Type of } \\
\text { assay for } \\
\text { NM }\end{array}$ & $\begin{array}{l}\text { Enrolled } \\
\text { population }\end{array}$ & $\begin{array}{l}\text { Type of } \\
\text { disrupting } \\
\text { factor }\end{array}$ & $\begin{array}{l}\text { Follow-up } \\
\text { post-treat-ment }\end{array}$ & $\begin{array}{l}\text { Claims stated } \\
\text { in papers }\end{array}$ & $\begin{array}{l}\text { Evidence- } \\
\text { based claim }\end{array}$ \\
\hline $\begin{array}{l}\text { L. rhamnosus GG+Lactobacillus } \\
\text { gasseri TMC0356 }\end{array}$ & Kubota et $a l^{103}$ & 14 & $\begin{array}{l}\text { Culture } \\
\text { FISH } \\
\text { TRFLP }\end{array}$ & $\begin{array}{l}\text { Healthy, allergy } \\
\text { patients }\end{array}$ & None & 0 & $\begin{array}{l}\text { Suppressed } \\
\text { changes }\end{array}$ & Alters \\
\hline $\begin{array}{l}\text { L. paracasei } \mathrm{B} 21060+L \text {. } \\
\text { paracasei } \mathrm{B} 21070+L \text {. gasseri } \\
\mathrm{B} 21090\end{array}$ & Morelli et al ${ }^{104}$ & 12 & Culture & Healthy volunteers & None & 3 days & No claims & No change \\
\hline $\begin{array}{l}\text { L. acidophilus } 1748+L \text {. } \\
\text { paracasei } \mathrm{F} 19+B \text {. lactis } \mathrm{Bb} 12\end{array}$ & Sullivan et $a l^{105}$ & 15 & Culture & $\begin{array}{l}\text { Chronic fatigue } \\
\text { patients }\end{array}$ & None & 4 weeks & No change & No change \\
\hline $\begin{array}{l}\text { L. rhamnosus } 271+L \text {. } \\
\text { acidophilus NCFM+L. paracasei } \\
114001+B \text {. animalis } 1017\end{array}$ & $\begin{array}{l}\text { Engelbrektson } \\
\text { et } a^{50}\end{array}$ & 22 & $\begin{array}{l}\text { Culture } \\
\text { TRFLP } \\
\text { PCR }\end{array}$ & Healthy volunteers & None & 2 weeks & No change & No change \\
\hline $\begin{array}{l}\text { B. animalis lactis }+ \text { Lactobacillus } \\
\text { delbrueckii I- } 1632+L \text {. delbrueckii } \\
\text { l-1519+L. lactis cremoris }\end{array}$ & McNulty et al ${ }^{106}$ & 7 & PCR & $\begin{array}{l}\text { Healthy twins } \\
\text { volunteers }\end{array}$ & None & 4 weeks & No change & No change \\
\hline $\begin{array}{l}\text { L. acidophilus }+L \text {. paracasei+ } L \text {. } \\
\text { delbrueckii spp bulgaricus }+L \text {. } \\
\text { plantarum+B. longum }+B \text {. } \\
\text { infantis }+B \text {. breve }\end{array}$ & Vital et $a l^{14}$ & 15 & PCR & $\begin{array}{l}\text { Healthy pregnant } \\
\text { volunteers }\end{array}$ & None & 0 & Modulates & No change \\
\hline
\end{tabular}


microbiota', but the only significant changes were due to an increase in the bacterial species contained in the probiotic mixture.

Of the probiotics supported by multiple clinical trials (B. animalis, B. longum, L. casei, $L$. plantarum $299 \mathrm{v}$, the mixture of $B$. animalis and B. lactis), 13 of the trials $(87 \%)$ support there is no significant change in normal microbiota if the microbiota is not disrupted (Strength: strong, Quality: low).

\section{Association of clinical efficacy and normal microbiota restoration}

Few studies concurrently compared clinical efficacy and the ability to restore or improve normal microbiota after dysbiosis. A synthesis of the literature of RCT for eight common disease indications was performed and the overall net strength was ranked. Probiotics with the ability to restore normal microbiota were frequently supported by RCTs for efficacy, as shown in table 4 . Of the 10 probiotics with evidence for restoration, $7(70 \%)$ also had at least one RCT testing for at least one of the eight diseases, while $30 \%$ did not have any supportive RCTs for efficacy. Of the seven probiotics with associated RCTs, only two probiotics (S. boulardii and L. acidophilus) have strong evidence for efficacy across most of the disease indications, while five probiotics with the ability to restore the microbiota had weak or no evidence of efficacy. For example, S. boulardii, which has studies supporting restoration, has strong evidence for clinical efficacy for AAD (ranked++: 11 RCTs had significant results and 6 had non-significant results), CDI (ranked++: had two RCTs with significant results), IBD (ranked++: had two RCTs with significant results), IBS (ranked 0: had one RCT with significant efficacy and one RCT with nonsignificant results), TD (ranked+: 3 RCTs with significant efficacy and 2 with non-significant efficacy), $H$. pylori eradication (ranked -: 2 RCTs with significant results and 4 with non-significant results) and no studies for BV. L. acidophilus, which partially restored the microbiota in a study, is associated with clinical efficacy for AAD, IBS and $\mathrm{BV}$, but not for TD or eradication of $H$. pylori and treatment of acute paediatric diarrhoea (ranked++: had 19 RCTs with significant protection and five with nonsignificant results). In contrast, L. rhamnosus $G G$, another probiotic capable of restoring microbiota, is often cited in meta-analysis as having significant efficacy for AAD. Our results of an updated review of the literature indicate a net weak evidence rating for clinical efficacy across all disease indications: AAD (ranked -: 3 RCTs had significant results and 6 had non-significant results), CDI (ranked -: two RCTs with non-significant results), IBD (ranked -: one RCT with non-significant results), IBS (ranked 0: 2 RCTs with significant efficacy and two RCTs with non-significant results), TD (ranked 0: one RCT with significant efficacy and one with non-significant efficacy), H. pylori eradication (ranked -: 3 RCTs with nonsignificant results), no RCTs for $\mathrm{BV}$ and treatment of acute paediatric diarrhoea (ranked++: 10 RCTs with significant efficacy and one with non-significant findings).

Efficacy trials were not carried out as frequently for probiotics shown to only have the ability to alter or improve, but not restore, the microbiota after dysbiosis. Of nine probiotics that can alter the microbiota, 6 $(67 \%)$ have supporting RCTs for at least one disease, but the diversity of investigated diseases was more limited. L. casei had moderate net strength for AAD and bacterial vaginosis, but was neutral for the ability to eradicate $H$. pylori and other disease indications were not tested in RCTs with $L$. casei. The probiotic mixture of $L$. reuteri and $L$. fermentum has strong evidence for bacterial vaginosis, but not for any other disease indications listed in table 4.

Of the eight probiotics not capable of altering or restoring normal microbiota, only L. plantarum $299 \mathrm{v}$ had RCTs for AAD and IBS, both with net negative or weak strength of clinical efficacy. B. lactis and the mixture of L. rhamnosus and $L$. reuteri had net neutral rankings for efficacy for the treatment of acute paediatric diarrhoea. The other four probiotic products with no effect on normal microbiota lacked any RCTs for clinical efficacy. Studies with Bacillus clausii did not assay for normal microbiota and had nonsignificant trial results for $H$. pylori eradication and the treatment of paediatric diarrhoea.

Of the six probiotics with only pharmacokinetic data on the probiotic itself and no other investigation of other normal microbiota strains, five had RCTs showing varying net efficacies for different disease indications, as shown in table 4.

Six popular probiotics (B. clausii, B. infantis, L. reuteri, $L$. acidophilus $+L$. helveticus, $L$. acidophilus $+L$. casei and $L$. acidophilus $+B$. animalis) have only clinical efficacy RCTs, but have not published studies investigating their role in restoring or improving the normal microbiota.

\section{DISCUSSION}

Developing and evaluating health or function claims for probiotics is an important issue and is now identified as a priority for research by several international organisations, including the World Gastroenterology Organization ${ }^{107}$ and the American Society for Nutrition. ${ }^{2}$ The US Food and Drug Administration has struggled with appropriate evidence-based health claims for probiotic products and currently recommends the use of structure/function claims, such as 'maintains bowel regularity', but the claim for restoring normal microbiota is still under debate. ${ }^{108}$ The European Food Safety Authority (EFSA) provides guidance materials that recommend health or function claims for probiotics should have beneficial physiological effects and have appropriate scientific trials to substantiate the health claims. ${ }^{3}$ Acceptable claims for intestinal health may include functional claims (improved transit time, softer stool consistency, reduction in gastrointestinal discomfort, defense against pathogens). As it is currently not possible to 
Table 4 Comparison of the ability of probiotic to restore or improve dysbiosis with ranked clinical efficacy for various disease indications

\begin{tabular}{|c|c|c|c|c|c|c|c|c|c|c|}
\hline \multirow[b]{2}{*}{ Probiotic $^{*}$} & \multirow[b]{2}{*}{$\begin{array}{l}\text { Restored } \\
\text { normal } \\
\text { microbiota* }\end{array}$} & \multirow[b]{2}{*}{$\begin{array}{l}\text { Altered } \\
\text { normal } \\
\text { microbiota* }\end{array}$} & \multicolumn{8}{|c|}{ Ranked net evidence for efficacyt } \\
\hline & & & AAD & CDI & IBD & IBS & TD & H pylori & $\begin{array}{l}\text { Vaginitis/ } \\
\text { BV }\end{array}$ & $\begin{array}{l}\text { Acute } \\
\text { paediatric } \\
\text { diarrhoea }\end{array}$ \\
\hline \multicolumn{11}{|l|}{ Restores microbiota } \\
\hline Clostridium butyricum MIYAIRI & Yes & ND & - & & & & & - & & \\
\hline Lactobacllius. acidophilus+Bifido bifidum & Yes & ND & 0 & - & & & & & & \\
\hline L. acidophilus $1748+$ Lactobacllius paracasei $\mathrm{F} 19+$ Bifido lactis $\mathrm{Bb} 12$ & Yes & ND & & & & - & & & & \\
\hline Bifido longum & Yes & No & & & - & + & & & & \\
\hline L. acidophilus $+L$. acidophilus $+B$. bifidum $+B$. animalis & Yes & ND & & & & & & & & \\
\hline L. acidophilus $+L$. paracasei+B. lactis (2) & Yes & No & & & & & & & & \\
\hline Saccharomyces boulardii lyo & Partial & Yes & ++ & ++ & ++ & 0 & + & - & & ++ \\
\hline L. rhamnosus GG & Partial & ND & - & - & - & 0 & 0 & - & 0 & ++ \\
\hline L. acidophilus & Partial & No & ++ & & & ++ & - & - & + & 0 \\
\hline L. acidophilus + L. bifidus + L. rhamnosus & Partial & ND & & & & & & & & \\
\hline \multicolumn{11}{|l|}{ Alters microbiota } \\
\hline Escherichia coli Nissle & ND & Yes & & & - & & & & & + \\
\hline L. casei (DN114001 or Lcr35) & ND & Yes & + & & & & & 0 & + & ++ \\
\hline L. rhamnosus GR1+Lactobacllius fermentum $\mathrm{RC} 14$ & ND & Yes & & & & & & & ++ & \\
\hline L. plantarum 8PA3+B. bifidum & ND & Yes & & & & & & & & \\
\hline $\begin{array}{l}\text { Lactobacllius rhamnosus } \mathrm{GG}+L \text {. rhamnosus } \mathrm{Lc} 705+P \text {. freudenreichii } \\
\text { shermanii JS+Bifido breve } \mathrm{Bb} 99\end{array}$ & ND & Yes & & & & ++ & & & & \\
\hline L. acidophilus+L. plantarum $+L$. rhamnosus $+B$ bifidum & ND & Yes & & & & & & & & \\
\hline Lactobacllius brevis CD2+Lactobacllius. salivarus FV2+L. plantarum FV9 & ND & Yes & & & & & & & + & \\
\hline $\begin{array}{l}\text { L. acidophilus }+L \text {. paracasei+Lactobacllius delbrueckii spp. bulgaricus }+L \text {. } \\
\text { plantarum, Bifido longum, Bifido infantis, Bifido breve }\end{array}$ & ND & Yes & - & & ++ & + & & & & ++ \\
\hline \multicolumn{11}{|l|}{ No effect on microbiota } \\
\hline Bacillus clausii & ND & ND & & & & & & - & & - \\
\hline L. plantarum $299 \mathrm{v}$ & ND & No & - & - & & - & & & & \\
\hline B. lactis & ND & No & + & & & & & & & 0 \\
\hline B. breve & No & No & & & & & & & & \\
\hline L. acidophilus $+B$. longum & No & ND & & & & & & & & \\
\hline L. rhamnosus $19070-2+L$. reuteri DSM & ND & No & & & & & & & & 0 \\
\hline L. casei+B. breve & ND & No & & & & & & & & \\
\hline L. paracasei+L. acidophilus $+B$ animalis & ND & No & & & & & & & & \\
\hline \multicolumn{11}{|l|}{ Pharmacokinetic only } \\
\hline L. reuteri 55730 & ND & ND & & & & & & & & + \\
\hline L. johnsonii La1 & ND & ND & & & - & & & + & & \\
\hline L. salivarius UCC4331 & ND & ND & & & & - & & & & \\
\hline B. infantis 35624 & ND & ND & & & & 0 & & & & \\
\hline B. bifidum MIMBb75 & ND & ND & & & & + & & & & \\
\hline L. rhamnosus+B. longum & ND & ND & & & & & & & & \\
\hline
\end{tabular}

*Including strain (when reported).

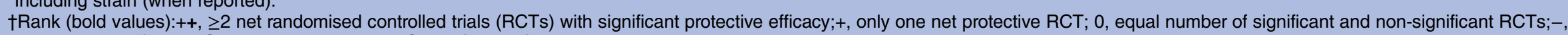
$\geq 1$ net non-significant RCT. Blank indicates no RCT performed for the disease indication.

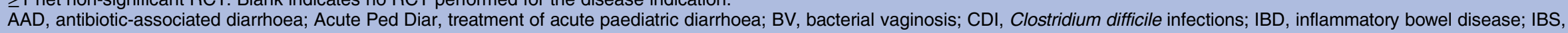
irritable bowel syndrome;ND, not determined; TD, traveler's diarrhoea. 
define a standard normal microbiota profile, the EFSA recommends functional claims for the restoration of normal microbiota should document a recovery of healthy microbiota and be accompanied by a beneficial physiological or clinical outcome. ${ }^{3}$ In addition, because the efficacy and mechanisms are strain-specific and may vary by probiotic strain, the evidence must be analysed for each probiotic product individually. ${ }^{5} 69$ 109-112

An underappreciated finding was the influence that study design and study populations have on the interpretation of study outcomes. In the literature, five different types of study designs are commonly found relating to probiotics. The most common study type is a randomised controlled trial testing the efficacy and safety outcomes in patients, but these trials did not typically document the impact of the probiotic on the normal microbiota. The second most common type of study design is pharmacokinetic studies (documenting recovery of oral dose of probiotic or increase in probiotic strains post-treatment compared to pretreatment or clearance of the probiotic). Even though these kinetic studies did not assay for non-probiotic strains, some extrapolated their results and concluded some effect or improvement of the normal microbiota was observed by their probiotic. ${ }^{19} 111$ These two first types of study designs do not support evidence-based conclusions for the restoration or alteration of the normal microbiota and were excluded from this review.

Three types of study designs are appropriate for the study of dysbiosis. The first type of study design had normal microbiota assayed at least twice (at baseline, which was before exposure to a disruptive event or probiotics and then again during or postprobiotic treatment) to show actual recovery of assayed normal microbiota back to healthy baseline levels. The second type of study design started with inappropriate baselines (baseline samples taken after normal microbiota had been disrupted by chronic disease). For patients with established chronic diseases, there is no "normal microbiota' baseline in either the probiotic or the control group. Even if baselines are taken during remission, the microbiota may still be impacted by chronic disease or acute diarrhoea. Studies of probiotics in chronic diseases or acute disease typically report on 'pre-probiotic treatment' and 'post-probiotic treatment' and may show significant shifts in microbial species, but it is uncertain if this reflects a true re-establishment of normal microbiota profiles. The third type of study design enrolled healthy volunteers, who were not challenged with antibiotics (so no normal microbiota disruption occurred) and show only the effect of probiotics on a healthy microbiota (typically mild or no effects). Control groups were not required for our assessment of the impact of probiotics on microbiota, but control groups can document the degree normal microbiota is disrupted by inciting agents (antibiotic, disease onset, etc).

Five single strain probiotics (B. longum, Clost. butyricum, L. acidophilus, L. rhamnosus and $S$. boulardii) and five probiotic mixtures ((L. acidophilus+B. bifidum), (L. rhamnosus+L. bifidus $+L$. acidophilus), ( $L$. acidophilus $+L$. paracasei+B. lactis), (L. acidophilus, 2 strains, B. bifidum, B. animalis) and (L. acidophilus $+L$. paracase $+B$. bifidum +2 strains of $B$. lactis)) documented either complete or partial recovery of normal microbiota (model A). Only two probiotic mixtures ( $(2$ strain mixture: L. acidophilus $+B$. bifidum) and (4 strain mixture: L. acidophilus, 2 strains, B. bifidum, B. animalis)) were supported by a confirmatory study. Evidence that probiotics may alter or improve normal microbiota (model B) was found for three single strain probiotics (E. coli Nissle, S. boulardii and $L$. casei rhamnosus) and seven mixtures of 2-7 probiotic strains. Of these 10 probiotics finding alteration of the microbiota, only three had multiple trials: $S$. boulardii, a four strain mixture (2 strains of $L$. rhamnosus $+P$. freudenreichii $+B$. breve), and a seven strain mixture (4 lactobacilli and 3 bifidobacteria strains), but only one had consistent results showing improvements in the microbiota. ${ }^{7475}$ Clearly, more than one study is needed to confirm the impact of a probiotic on the normal microbiota. Of the 19 probiotic strains (or mixtures) studied in healthy volunteers who were not exposed to disruptive factors (model $\mathrm{C}$ ), no change in the normal microbiota was observed for $79 \%$, indicating the robustness of the microbiota.

Improvement in the normal microbiota by specific probiotic strains seemed to be associated with better clinical end points. Within eight common diseases typically treated with probiotics, more trials with significant efficacy were associated with probiotic strains shown to restore the normal microbiota and only one trial with significant efficacy was found for probiotics that did not alter the microbiota. However, few probiotics had efficacy trials for all eight diseases and many did not have any efficacy trials.

Some probiotics which have published efficacy trials for various diseases did not have studies investigating the effect of the probiotic on normal microbiota: B. clausii, $B$. infantis, L. brevis, L. reuteri, mix of two strains ( $L$. acidophilus $+L$. helveticus), mix of two strains ( $L$. acidophilus $+L$. casei) or (L. acidophilus+B. animalis), mix of four strains (L. rhamnosus (two strains), P. freudenreichii $+B$. animalis)) and mix of seven strains (L. sporogens, L. bifidum, L. bulgaricus, L. thermophilus, L. acidophilus, L. casei, L. rhamnosus).

\section{Comparison of results with other studies}

Other reviews in the literature of claims for probiotics relating to changes in the normal microbiota have focused on the broad issues of regulatory standardisation of health or function claims, the use of proper study designs and the challenge of defining biomarkers for a 'healthy microbiota'. ${ }^{3} 29112$ Donovan $e t a l^{2}$ recommends that health claims for probiotics be supported by wellconducted human trials in the targeted population. These reviews also recommend that gut biomarkers need to be correlated with clinical endpoints, however 
none of these reviews attempted to do so. ${ }^{29} 112$ No prior review has attempted to analyse the association between probiotic strains and their impact on normal microbiota by stratifying on the quality of study design. ${ }^{111}$ This review addressed these concerns by analysing probiotic strains by the quality of the study design and only including trials that assessed the normal microbiota (either by microbial culturing or molecular strain biomarkers) and assessed the degree of dysbiosis improvement with clinical outcomes for each probiotic strain.

\section{Opportunities for future research}

Most of the studies (80\%) using model A to document restoration of the normal microbiota only used microbiological culturing techniques, which can only detect those organisms that grow in culture. Use of the more advanced molecular metagenomic techniques have found that culturing alone misses up to $95 \%$ of these organisms. ${ }^{21} 22$ The use of the metagenomic techniques was more common in the studies using model B (48\%) and model C (45\%) study designs, which only addresses potential alteration of the microbiota. Characterisation of the microbiota is a complex issue and a comprehensive accounting of all the bacterial and fungal strains in the body is beyond our current capabilities. Therefore, any studies of changes to the microbiota are incomplete at best, but general trends in bacterial phylotypes can be documented using DNA probes and metagenomic techniques. Differential detection bias may be present due to the variety of assays used in these studies and should be accounted for in future studies.

Another suggestion for future studies is to include an appropriate follow-up time period postprobiotic administration. Fewer than half of the reviewed trials did assays for normal microbiota during an appropriate follow-up period. As it has been shown that recovery from a disrupting factor can be prolonged (typically 8 weeks), ${ }^{7} 8$ and studies that failed to find microbiota recovery might have detected a return to normal baseline levels if a sufficiently long time was given for the recovery to have occurred. Future studies should strive to allow time for the restoration of the normal microbiota to occur.

As the effects of probiotics are strain specific, and many studies typically only report the genus and species of the tested probiotic, future reports should include a complete description of the probiotic to the stain level. $^{5} 112$

\section{Strengths and weaknesses}

The strengths of this review included the completeness of the search strategy, which reviewed multiple citation databases, trial registries and author searches, use of established PRISMA protocols for reviews and the use of an outcome classification scheme for different degrees of assessment for microbial recovery. This analysis controlled the confounding effects of different study populations and study designs present in the literature. Pharmacokinetic studies of just the probiotic strain(s) itself were excluded and only trials that assayed other species found in the microbiota were included. By applying a standard definition for 'restoring' versus 'improving' normal microbiota, it is possible to distinguish significant differences by the type of study designs used and differential effects of the different probiotic strains. Limitations of this review include: a single author reviewed and extracted the literature, pooling trials from different populations (adult vs paediatric) and different probiotic doses and regimens used. Incomplete retrieval of all studies assessing the effect that probiotics have on human microbiota is also a potential limitation of any literature search. Another limitation is that dysbiosis improvement and clinical efficacy for probiotic strains is also indirectly associated, no direct cause and effect relationship was possible with the types of studies carried out. Another limitation is the current lack of a standard definition of what comprises a 'normal microbiota'. The constituents of the microbiota vary by individual, by age, geographic location and health status of the host. Current microbiological techniques are improving, but cannot detect all species present in the host.

\section{CONCLUSION}

The challenges in recommending a specific probiotic to patients who need to restore or improve their normal microbiota after a disrupting event occurs is twofold: one is the diversity of probiotic products available and second is the varying strength of evidence provided by clinical trials using different outcome measures and study designs. By grouping studies into three groups that result in three different degrees of probiotic effect (restoration, improvement or no change), an overview of the body of evidence is possible. By comparing the strength of the clinical evidence for common diseases by the degree to which the probiotics could impact the restoration of the normal microbiota, it became obvious that those probiotics with a greater ability to restore the microbiota are associated with the strongest strength of clinical efficacy. While this evidence only indirectly links clinical efficacy with the ability to restore the microbiota, the overall review of the evidence shows this is an important mechanism of action for probiotics. What becomes obvious is that more studies are required to conclude which probiotic strains have a beneficial impact on the normal microbiota, as most strains have only a single clinical trial and many probiotic products overstate the strength of their claim to restore normal microbiota. These types of issues should be considered for healthcare policymakers and researchers for future studies and for creating guidelines for health/function claims.

Funding This research received no specific grant from any funding agency in the public, commercial or not-for-profit sectors.

Competing interests The author has been a paid lecturer for the following companies: Biocodex, Inc and Lallemand. The author is a member of the Scientific Advisory Board for BioK Plus International. Biocodex Inc provided travel expenses for the author to a scientific meeting. 
Provenance and peer review Not commissioned; externally peer reviewed.

Data sharing statement No additional data are available.

Open Access This is an Open Access article distributed in accordance with the Creative Commons Attribution Non Commercial (CC BY-NC 4.0) license which permits others to distribute, remix, adapt, build upon this work noncommercially, and license their derivative works on different terms, provided the original work is properly cited and the use is non-commercial. See: http:// creativecommons.org/licenses/by-nc/4.0/

\section{REFERENCES}

1. Katan MB. Why the European Food Safety Authority was right to reject health claims for probiotics. Benef Microbes 2012;3:85-9.

2. Donovan SM, Schneeman B, Gibson GR, et al. Establishing and evaluating health claims for probiotics. Amer Soc Nutr Adv Nutri 2012;3:723-5.

3. European Food Safety Authority (EFSA). Guidance on the scientific requirements for health claims related to gut and immune function. EFSA J 2011;9:1984.

4. Binnendijk KH, Rijkers GT. What is a health benefit? An evaluation of EFSA opinions on health benefits with reference to probiotics. Benef Microbes 2013;4:223-30.

5. McFarland LV. Systematic review and meta-analysis of Saccharomyces boulardii in adult patients. World J Gastroenterol 2010;16:2202-22.

6. Buts JP, Stilmant C, Bernasconi P, et al. Characterization of alpha, alpha-trehalase released in the intestinal lumen by the probiotic Saccharomyces boulardii. Scand J Gastroenterol 2008;43:1489-96.

7. McFarland LV. Antibiotic-associated diarrhea: epidemiology, trends and treatment. Future Microbiol 2008;3:563-78.

8. Dethlefsen L, Huse S, Sogin ML, et al. The pervasive effects of an antibiotic on the human gut microbiota, as revealed by deep $16 \mathrm{~S}$ rRNA sequencing. PLoS Biol 2008;6:e280.

9. McFarland LV. Normal flora: diversity and functions. Microb Ecol Health Dis 2000;12:193-207.

10. Sanders ME. Impact of probiotics on colonizing microbiota of the gut. J Clin Gasteroenterol 2011;45:S115-19.

11. Young VB, Schmidt TM. Antibiotic-associated diarrhea accompanied by large-scale alterations in the composition of the fecal microbiota. J Clin Microbiol 2004;42:1203-6.

12. Nylund L, Satokari R, Nikkilä J, et al. Microarray analysis reveals marked intestinal microbiota aberrancy in infants having eczema compared to healthy children in at-risk for atopic disease. BMC Microbiol 2013;13:12.

13. Prince T, McBain AJ, O'Neill CA. Lactobacillus reuteri protects epidermal keratinocytes from Staphylococcus aureus-induced cell death by competitive exclusion. Appl Environ Microbiol 2012:78:5119-26.

14. Vitali B, Cruciani F, Baldassarre ME, et al. Dietary supplementation with probiotics during late pregnancy: outcome on vaginal microbiota and cytokine secretion. BMC Microbiol 2012;12:236.

15. Nugent RP, Krohn MA, Hillier SL. Reliability of diagnosing bacterial vaginosis is improved by a standardized method of Gram stain interpretation. J Clin Microbiol 1991;29:297-301.

16. Ciprandi G, Vizzaccaro A, Cirillo I, et al. Bacillus clausii exerts immuno-modulatory activity in allergic subjects: a pilot study. Eur Ann Allergy Clin Immunol 2005;37:129-34.

17. Marseglia GL, Tosca M, Cirillo I, et al. Efficacy of Bacillus clausii spores in the prevention of recurrent respiratory infections in children: a pilot study. Ther Clin Risk Manag 2007;3:13-17.

18. Iniesta M, Herrera D, Montero E, et al. Probiotic effects of orally administered Lactobacillus reuteri-containing tablets on the subgingival and salivary microbiota in patients with gingivitis. A randomized clinical trial. J Clin Periodontol 2012;39:736-44.

19. Shah MP, Gujjari SK, Chandrasekhar VS. Evaluation of the effect of probiotic (inersan) alone, combination of probiotic with doxycycline and doxycycline alone on aggressive periodontitis-a clinical and microbiological study. J Clin Diagn Res 2013;7:595-600.

20. Teughels W, Durukan A, Ozcelik O, et al. Clinical and microbiological effects of Lactobacillus reuteri probiotics in the treatment of chronic periodontitis: a randomized placebo-controlled study. J Clin Periodontol 2013;40:1025-35.

21. Kleessen B, Bezirtzoglou E, Matto J. Culture-based knowledge on biodiversity, development and stability of human gastrointestinal microflora. Micro Ecol Health Dis 2000;12:53-63.
22. Schmeisser C, Steele H, Streit WR. Metagenomics, biotechnology with non-culturable microbes. Appl Microbiol Biotechnol 2007;75:955-62.

23. Preidis GA, Versalovic J. Targeting the human microbiome with antibiotics, probiotics, and prebiotics: gastroenterology enters the metagenomics era. Gastroenterol 2009;136:2015-31.

24. Aagaard K, Petrosino J, Keitel W, et al. The Human Microbiome Project strategy for comprehensive sampling of the human microbiome and why it matters. FASEB J 2013;27:1012-22.

25. Handelsman J. Metagenomics: application of genomics to uncultured microorganisms. Micro Mol Biol Rev 2004;68:669-85.

26. Gill SR, Pop M, Deboy RT, et al. Metagenomic analysis of the human distal gut microbiome. Science 2006;312:1355-9.

27. Frank DN, Pace NR. Gastrointestinal microbiology enters the metagenomics era. Curr Opin Gastroenterol 2008;24:4-10.

28. Swidsinski A, Loening-Baucke V, Kirsch S, et al. Functional biostructure of colonic microbiota (central fermenting area, germinal stock area and separating mucus layer) in healthy subjects and patients with diarrhea treated with Saccharomyces boulardii]. Gastroenterol Clin Biol 2010;34(Suppl 1):S79-92.

29. Sanders ME, Guarner F, Guerrant R, et al. An update on the use and investigation of probiotics in health and disease. Gut 2013;62:787-96

30. Moher D, Liberati A, Tetzlaff J, et al. Preferred reporting items for systematic reviews and meta-analyses: the PRISMA statement. BMJ 2009;339:332-6.

31. Franks $\mathrm{AH}$, Harmsen $\mathrm{HJ}$, Raangs $\mathrm{GC}$, et al. Variations of bacterial populations in human feces measured by fluorescent in situ hybridization with group-specific 16S rRNA-targeted oligonucleotide probes. Appl Environ Microbiol 1998;64:3336-45.

32. Wada M, Nagata S, Saito M, et al. Effects of the enteral administration of Bifidobacterium breve on patients undergoing chemotherapy for pediatric malignancies. Support Care Cancer 2010;18:751-9.

33. Odamaki T, Xiao JZ, Iwabuchi N, et al. Influence of Bifidobacterium longum BB536 intake on faecal microbiota in individuals with Japanese cedar pollinosis during the pollen season. J Med Microbiol 2007;56(Pt 10):1301-8.

34. Seki $\mathrm{H}$, Shiohara M, Matsumura $\mathrm{T}$, et al. Prevention of antibiotic-associated diarrhea in children by Clostridium butyricum MIYAIRI. Pediatr Int 2003;45:86-90.

35. Mustafa RA, Santesso N, Brozek J, et al. The GRADE approach is reproducible in assessing the quality of evidence of quantitative evidence syntheses. J Clin Epidemiol 2013:66:736-42.

36. McFarland LV. Meta-analysis of probiotics for prevention of antibiotic associated diarrhea and treatment of Clostridium difficile disease. Am J Gastroenterol 2006;101:812-22.

37. McFarland LV, Goh S. Preventing pediatric antibiotic-associated diarrhea and Clostridium difficile infections with probiotics: a meta-analysis. World J Meta Anal 2013;1:102-20.

38. Goldenberg JZ, Ma SS, Saxton JD, et al. Probiotics for the prevention of Clostridium difficile-associated diarrhea in adults and children. Cochrane Database Syst Rev 2013;5:CD006095.

39. Shen J, Zuo Z, Mao A. Effect of probiotics on inducing remission and maintaning therapy in ulcerative colitis, Crohn's disease, and pouchitis: meta-analysis of randomized controlled trials. Inflamm Bowel Dis 2014;20:21-35.

40. McFarland LV, Dublin S. Meta-analysis of probiotics for the treatment of irritable bowel syndrome. World J Gastroenterol 2008;14:2650-61.

41. McFarland LV. Meta-analysis of probiotics for the prevention of traveler's diarrhea. Travel Med Infect Dis 2007;5:97-105

42. Huang $\mathrm{H}$, Song $\mathrm{L}$, Zhao $\mathrm{W}$. Effects of probiotics for the treatment of bacterial vaginosis in adult women: a meta-analysis of randomized controlled trials. Arch Gynecol Obstet 2014;289:1225-34.

43. McFarland LV, Elmer GW, McFarland M. Meta-analysis of probiotics for the prevention and treatment of acute pediatric diarrhea. Intern/ J Probiotics Prebiotics 2006;1:63-76.

44. Dinleyici EC, Eren M, Ozen M, et al. Effectiveness and safety of Saccharomyces boulardii for acute infectious diarrhea. Expert Opin Biol Ther 2012:12:395-410.

45. Szajewska H, Ruszczyński M, Kolaček S. Meta-analysis shows limited evidence for using Lactobacillus acidophilus LB to treat acute gastroenteritis in children. Acta Paediatr 2014;103:249-55.

46. Alvaro $\mathrm{E}$, Andrieux $\mathrm{C}$, Rochet $\mathrm{V}$, et al. Composition and metabolism of the intestinal microbiota in consumers and non-consumers of yogurt. Br J Nutr 2007;97:126-33.

47. Zubadalashvili NG, Makhviladze MA, Diasamidze MT, et al. [The comparative study of Linex and Lacto-G in treatment of adult patients with disbacteriosis]. Russian. Georgian Med News 2009;170:38-42. 
48. Klein SM, Elmer GW, McFarland LV, et al. Recovery and elimination of the biotherapeutic agent, Saccharomyces boulardii, in healthy human volunteers. Pharm Res 1993;10:1615-19.

49. Rochet V, Rigottier-Gois L, Ledaire A, et al. Survival of Bifidobacterium animalis DN-173 010 in the faecal microbiota after administration in lyophilised form or in fermented product-a randomised study in healthy adults. $\mathrm{J} \mathrm{Mol} \mathrm{Microbiol} \mathrm{Biotechnol}$ 2008;14:128-36.

50. Engelbrektson AL, Korzenik JR, Sanders ME, et al. Analysis of treatment effects on the microbial ecology of the human intestine. FEMS Microbiol Ecol 2006;57:239-50.

51. Zoppi G, Cinquetti M, Benini A, et al. Modulation of the intestinal ecosystem by probiotics and lactulose in children during treatment with ceftriaxone. Curr Ther Res 2001;62:418-35.

52. Orrhage K, Brismar B, Nord CE. Effects of supplements of Bifidobacterium longum and Lactobacillus acidophilus on the intestinal microbiota during administration of clindamycin. Microb Ecol Health Dis 1994;7:17-25.

53. Larsen N, Vogensen FK, Gøbel R, et al. Predominant genera of fecal microbiota in children with atopic dermatitis are not altered by intake of probiotic bacteria Lactobacillus acidophilus NCFM and Bifidobacterium animalis subsp. lactis Bi-07. FEMS Microbiol Ecol 2011;75:482-96.

54. Lidbeck A, Edlund C, Gustafsson JA, et al. Impact of Lactobacillus acidophilus on the normal intestinal microflora after administration of two antimicrobial agents. Infection 1988;16:329-36.

55. Black F, Einarsson K, Lidbeck A, et al. Effect of lactic acid producing bacteria on the human intestinal microflora during ampicillin treatment. Scand J Infect Dis 1991;23:247-54.

56. Jernberg C, Sullivan A, Edlund C, et al. Monitoring of antibioticinduced alterations in the human intestinal microflora and detection of probiotic strains by use of terminal restriction fragment length polymorphism. Appl Environ Microbiol 2005;71:501-6.

57. Madden JA, Plummer SF, Tang J, et al. Effect of probiotics on preventing disruption of the intestinal microflora following antibiotic therapy: a double-blind, placebo-controlled pilot study. Int Immunopharmacol 2005;5:1091-7.

58. Plummer SF, Garaiova I, Sarvotham T, et al. Effects of probiotics on the composition of the intestinal microbiota following antibiotic therapy. Int J Antimicrob Agents 2005;26:69-74.

59. van der Aa LB, Heymans HS, van Aalderen WM, et al. Effect of a new synbiotic mixture on atopic dermatitis in infants: a randomized-controlled trial. Clin Exp Allergy 2010;40:795-804.

60. Lata J, Novotný I, Príbramská V, et al. The effect of probiotics on gut flora, level of endotoxin and Child-Pugh score in cirrhotic patients: results of a double-blind randomized study. Eur $J$ Gastroenterol Hepatol 2007;19:1111-13.

61. Petricevic L, Witt A. The role of Lactobacillus casei rhamnosus Lcr35 in restoring the normal vaginal flora after antibiotic treatment of bacterial vaginosis. BJOG 2008;115:1369-74.

62. Nobaek S, Johansson ML, Molin G, et al. Alteration of intestinal microflora is associated with reduction in abdominal bloating and pain in patients with irritable bowel syndrome. Am J Gastroenterol 2000;95:1231-8.

63. Klarin B, Johansson ML, Molin G, et al. Adhesion of the probiotic bacterium Lactobacillus plantarum $299 \mathrm{v}$ onto the gut mucosa in critically ill patients: a randomised open trial. Crit Care 2005;9: R285-93.

64. Klarin B, Molin G, Jeppsson B, et al. Use of the probiotic Lactobacillus plantarum 299 to reduce pathogenic bacteria in the oropharynx of intubated patients: a randomised controlled open pilot study. Crit Care 2008;12:R136.

65. Girard-Pipau F, Pompei A, Schneider S, et al. Intestinal microflora, short chain and cellular fatty acids, influence of a probiotic $S$. boulardii. Microb Ecology Health Dis 2002;14:220-7.

66. Swidsinski A, Loening-Baucke $\mathrm{V}$, Verstraelen $\mathrm{H}$, et al. Biostructure of fecal microbiota in healthy subjects and patients with chronic idiopathic diarrhea. Gastroenterology 2008;135:568-79.

67. Reid G, Beuerman D, Heinemann C, et al. Probiotic Lactobacillus dose required to restore and maintain a normal vaginal flora. FEMS Immunol Med Microbiol 2001;32:37-41.

68. Reid G, Charbonneau D, Erb J, et al. Oral use of Lactobacillus rhamnosus GR-1 and L. fermentum RC-14 significantly alters vaginal flora: randomized, placebo-controlled trial in 64 healthy women. FEMS Immunol Med Microbiol 2003;35:131-4.

69. Kirpich IA, Solovieva NV, Leikhter SN, et al. Probiotics restore bowel flora and improve liver enzymes in human alcohol-induced liver injury: a pilot study. Alcohol 2008;42:675-82.

70. Hummelen R, Changalucha J, Butamanya NL, et al. Lactobacillus rhamnosus GR-1 and $L$. reuteri RC-14 to prevent or cure bacterial vaginosis among women with HIV. Int $J$ Gynaecol Obstet 2010;111:245-8.

71. Uchida K, Takahashi T, Inoue M, et al. Immunonutritional effects during synbiotics therapy in pediatric patients with short bowel syndrome. Pediatr Surg Int 2007;23:243-8.

72. Mastromarino P, Macchia S, Meggiorini L, et al. Effectiveness of Lactobacillus-containing vaginal tablets in the treatment of symptomatic bacterial vaginosis. Clin Microbiol Infect 2009;15:67-74.

73. Roessler A, Forssten SD, Glei M, et al. The effect of probiotics on faecal microbiota and genotoxic activity of faecal water in patients with atopic dermatitis: a randomized, placebo-controlled study. Clin Nutr 2012;31:22-9.

74. Kajander $\mathrm{K}$, Hatakka $\mathrm{K}$, Poussa $\mathrm{T}$, et al. A probiotic mixture alleviates symptoms in irritable bowel syndrome patients: a controlled 6 month intervention. Aliment Pharmacol Ther 2005;22:387-94.

75. Lyra A, Krogius-Kurikka L, Nikkilä J, et al. Effect of a multispecies probiotic supplement on quantity of irritable bowel syndrome-related intestinal microbial phylotypes. BMC Gastroenterol 2010;10:110.

76. Wong VW, Tse CH, Lam TT, et al. Molecular characterization of the fecal microbiota in patients with nonalcoholic steatohepatitis-a longitudinal study. PLoS ONE 2013;8:e62885.

77. Venturi $A$, Gionchetti $P$, Rizzello $F$, et al. Impact on the composition of the faecal flora by a new probiotic preparation: preliminary data on maintenance treatment of patients with ulcerative colitis. Aliment Pharmacol Ther 1999;13:1103-8.

78. Brigidi P, Vitali B, Swennen E, et al. Effects of probiotic administration upon the composition and enzymatic activity of human fecal microbiota in patients with irritable bowel syndrome or functional diarrhea. Res Microbiol 2001;152:735-41.

79. Kuhbacher T, Ott SJ, Helwig U, et al. Bacterial and fungal microbiota in relation to probiotic therapy (VSL\#3) in pouchitis. Gut 2006;55:833-41.

80. Ng SC, Lam ERC, Lam TTY, et al. Effect of probiotic bacteria on the intestinal microbiota in irritable bowel syndrome. J Gastroenterol Hepatol 2013;28:1624-31.

81. Oswari H, Prayitno L, Dwipoerwantoro PG, et al. Comparison of stool microbiota compositions, stool alpha1-antitrypsin and calprotectin concentrations, and diarrhoeal morbidity of Indonesian infants fed breast milk or probiotic/prebiotic-supplemented formula. J Paediatr Child Health 2013;49:1032-9.

82. Langhendries JP, Detry J, Van Hees J, et al. Effect of a fermented infant formula containing viable Bifidobacteria on the fecal flora composition and $\mathrm{pH}$ of healthy full-term infants. $J \mathrm{Ped}$ Gastroenterol Nutr 1995;21:177-81.

83. Benno Y, Mitsuoka T. Impact of Bifidobacterium longum on human fecal microflora. Microbiol Immunol 1992;36:683-94.

84. Fujiwara S, Seto $\mathrm{Y}$, Kimura A, et al. Intestinal transit of an orally administered streptomycin-rifampicin-resistant variant of Bifidobacterium longum SBT2928: its long-term survival and effect on the intestinal microflora and metabolism. $J$ Appl Microbiol 2001;90:43-52.

85. Harmsen HJ, Raangs GC, Franks AH, et al. The effect of the prebiotic inulin and the probiotic Bifidobacterium longum on the fecal microflora of healthy volunteers measured by FISH and DGGE. Micro Ecol Health Dis 2002;14:211-19.

86. Guerin-Danan C, Chabanet C, Pedone C, et al. Milk fermented with yogurt cultures and Lactobacillus casei compared with yogurt and gelled milk: influence on intestinal microflora in healthy infants. $A m$ J Clin Nutri 1998;67:111-17.

87. Rochet V, Rigottier-Gois L, Sutren M, et al. Effects of orally administered Lactobacillus casei DN-114 001 on the composition or activities of the dominant faecal microbiota in healthy humans. $\mathrm{Br} \mathrm{J}$ Nutr 2006;95:421-9.

88. Rochet V, Rigottier-Gois L, Levenez F, et al. Modulation of Lactobacillus casei in ileal and fecal samples from healthy volunteers after consumption of a fermented milk containing Lactobacillus casei DN-114 001. Can J Microbiol 2008:54:660-7.

89. Brunser $\mathrm{O}$, Gotteland $\mathrm{M}$, Cruchet $\mathrm{S}$, et al. Effect of a milk formula with prebiotics on the intestinal microbiota of infants after an antibiotic treatment. Pediatr Res 2006;59:451-6.

90. Goossens D, Jonkers D, Russel M, et al. The effect of Lactobacillus plantarum 299v on the bacterial composition and metabolic activity in faeces of healthy volunteers: a placebo-controlled study on the onset and duration of effects. Aliment Pharmacol Ther 2003;18:495-505.

91. Goossens $D$, Jonkers $D$, Russel $M$, et al. Survival of the probiotic, L. plantarum 299v and its effects on the faecal bacterial flora, with and without gastric acid inhibition. Dig Liver Dis 2005;37:44-50. 
92. Goossens DA, Jonkers DM, Russel MG, et al. The effect of a probiotic drink with Lactobacillus plantarum $299 \mathrm{v}$ on the bacterial composition in faeces and mucosal biopsies of rectum and ascending colon. Aliment Pharmacol Ther 2006;23:255-63.

93. Berggren A, Soderberg L, Onning G, et al. Intestinal function, microflora and nutrient intake of children after administration of a fermented oat product containing Lactobacillus plantarum DSM 9843(299v). Microb Ecol Health Dis 2003;15:160-8.

94. Karlsson C, Ahrné S, Molin G, et al. Probiotic therapy to men with incipient arteriosclerosis initiates increased bacterial diversity in colon: a randomized controlled trial. Atherosclerosis 2010;208:228-33.

95. Gueimonde M, Sakata S, Kalliomäki M, et al. Effect of maternal consumption of lactobacillus GG on transfer and establishment of fecal bifidobacterial microbiota in neonates. J Pediatr Gastroentero Nutr 2006;42:166-70.

96. Sierra S, Lara-Villoslada F, Sempere L, et al. Intestinal and immunological effects of daily oral administration of Lactobacillus salivarius CECT5713 to healthy adults. Anaerobe 2010;16:195-200.

97. Vanhoutte T, De Preter V, De Brandt E, et al. Molecular monitoring of the fecal microbiota of healthy human subjects during administration of lactulose and Saccharomyces boulardii. Appl Environ Microbiol 2006;72:5990-7.

98. Zhong Y, Huang CY, He T, et al. [Effect of probiotics and yogurt on colonic microflora in subjects with lactose intolerance]. Wei Sheng Yan Jiu 2006;35:587-91.

99. He T, Priebe MG, Zhong Y, et al. Effects of yogurt and bifidobacteria supplementation on the colonic microbiota in lactose-intolerant subjects. J Appl Microbiol 2008;104:595-604.

100. Yang YJ, Sheu BS. Probiotics-containing yogurts suppress Helicobacter pylori load and modify immune response and intestinal microbiota in the Helicobacter pylori-infected children. Helicobacter 2012;17:297-304.

101. Mah KW, Chin VI, Wong WS, et al. Effect of a milk formula containing probiotics on the fecal microbiota of Asian infants at risk of atopic diseases. Pediatr Res 2007;62:674-9.
102. Rafter J, Bennett M, Caderni G, et al. Dietary synbiotics reduce cancer risk factors in polypectomized and colon cancer patients. Am J Clin Nutr 2007;85:488-96.

103. Kubota A, He F, Kawase M, et al. Lactobacillus strains stabilize intestinal microbiota in Japanese cedar pollinosis patients. Microbiol Immunol 2009;53:198-205.

104. Morelli L, Zonenschain D, Callegari ML, et al. Assessment of a new synbiotic preparation in healthy volunteers: survival, persistence of probiotic strains and its effect on the indigenous flora. Nutr J 2003;2:11.

105. Sullivan A, Nord CE, Evengard B. Effect of supplement with lactic-acid producing bacteria on fatigue and physical activity in patients with chronic fatigue syndrome. Nutr J 2009;8:1-6.

106. McNulty NP, Yatsunenko T, Hsiao A, et al. The impact of a consortium of fermented milk strains on the gut microbiome of gnotobiotic mice and monozygotic twins. Sci Transl Med 2011;3:106ra106.

107. Guarner F, Khan AG, Garisch J, et al.; World Gastroenterology Organization. World Gastroenterology Organisation Global Guidelines: probiotics and prebiotics October 2011. J Clin Gastroenterol 2012;46:468-81.

108. United States Department of Health and Human Services Food and Drug Administration, Center for Food Safety and Applied Nutrition. Dietary Supplements Guidance Documents and Regulatory Information. 2008. http://www.fda/gov/food/ guidanceregulation/guidancedocumentsregulatoryinformation/ dietarysupplements/default.htm (accessed 29 May 2014).

109. Barc MC, Charrin-Sarnel C, Rochet V, et al. Molecular analysis of the digestive microbiota in a gnotobiotic mouse model during antibiotic treatment: influence of Saccharomyces boulardii. Anaerobe 2008;14:229-33.

110. O'Hara AM, Shanahan $\mathrm{F}$. The gut flora as a forgotten organ. EMBO Rep 2006;7:688-93

111. Masood MI, Qadir MI, Shirazi JH, et al. Beneficial effects of lactic acid bacteria on human beings. Crit Rev Microbiol 2011;37:91-8.

112. Rijkers GT, de Vos WM, Brummer RJ, et al. Health benefits and health claims of probiotics: bridging science and marketing. $\mathrm{Br} J$ Nutr 2011;106:1291-6. 